Article

\title{
Variable Future-Time Expression in Spanish: A Comparison between Heritage and Second Language Learners
}

\author{
Ana de Prada Pérez ${ }^{1, *(1)}$, Inmaculada Gómez Soler $^{2}\left[\right.$ and Nick Feroce ${ }^{3,4}(\mathbb{C})$ \\ 1 Department of Spanish and Latin American Studies, School of Modern Languages, Literatures, and Cultures, \\ Maynooth University, W23 F2H6 Maynooth, Co. Kildare, Ireland \\ 2 School of Applied Language and Intercultural Studies, Dublin City University, Glasnevin, Dublin 9, \\ D09 FW22 Dublin, Ireland; inmaculada.gomezsoler@dcu.ie \\ 3 Department of Linguistics, University of Kansas, Lawrence, KS 66045, USA; nferoce1@gmail.com \\ 4 Impact and Efficacy Research, Lexia Learning, Concord, MA 01742, USA; nick.feroce@lexialearning.com \\ * Correspondence: Ana.dePradaPerez@mu.ie; Tel.: +353-1-708-6078
}

Citation: Prada Pérez, Ana de, Inmaculada Gómez Soler, and Nick Feroce. 2021. Variable Future-Time Expression in Spanish: A Comparison between Heritage and Second Language Learners. Languages 6: 206 https://doi.org/10.3390/ languages6040206

Academic Editor: Aarnes Gudmestad

Received: 12 July 2021

Accepted: 22 November 2021

Published: 10 December 2021

Publisher's Note: MDPI stays neutral with regard to jurisdictional claims in published maps and institutional affiliations.

Copyright: (C) 2021 by the authors. Licensee MDPI, Basel, Switzerland. This article is an open access article distributed under the terms and conditions of the Creative Commons Attribution (CC BY) license (https:/ / creativecommons.org/licenses/by/ $4.0 /)$.

\begin{abstract}
This paper examines the expression of futurity in Spanish, specifically the periphrastic future (PF), the morphological future (MF), and the present indicative (PI) in heritage language learners (HLLs) and second language learners (L2 learners), a comparison that allowed us to explore whether linguistic experience provides HLLs an advantage over L2 learners in the domain of morphosyntax. These forms (PF, MF, and PI) are regulated by certainty, temporal distance, and the presence of temporal adverbials. Previous research showed that L2 learners acquire some of these linguistic constraints and that HLLs tend to reduce the MF to modal uses. Data from a contextualized acceptability judgment task completed by 46 HLLs and 42 L2ers manipulated for verb form, certainty, temporal distance, and adverb and revealed that (i) the PF and the MF were generally rated higher than the PI, (ii) HLLs were sensitive to the three linguistic factors examined, while the L2ers' sensitivity was modulated by proficiency, and, relatedly, (iii) the two groups differed in the effect of proficiency. For the L2 learners, an increase in proficiency led to a closer pattern to that of monolingual native speakers (only for temporal distance). Differences in exposure to and instruction in Spanish are discussed as possible sources of these differences.
\end{abstract}

Keywords: future-time expression; morphosyntactic variation; heritage language learners; second language learners

\section{Introduction}

This study contributes to the literature on the acquisition of morphosyntactic phenomena among different populations of multicompetent speakers, namely, heritage language learners (HLLs) and second language learners (L2 learners). Within a variationist framework, we focus specifically on the acquisition of future-time expression, a variable morphosyntactic phenomenon in which several variants overlap functionally within the same context (Geeslin and Long 2014).

In the context of the United States (US), Valdés (2000) defined a heritage speaker $\left(\mathrm{HS}^{1}\right)$ as someone who was raised in a home where a non-English language was spoken, who speaks or at least understands the language, and who is to some degree bilingual in that language (in our case, Spanish) and in English. From an acquisition perspective, HSs are an interesting population because their acquisition process possesses unique characteristics that separate them from monolingual speakers, as well as from L2 learners. Like monolingual speakers, they were exposed to the heritage language (HL) since birth naturalistically but, unlike monolingual speakers, they have limited access to Spanish input and usually limited literacy skills in the HL. If we compare them with L2 learners, these two populations differ in several respects in terms of when and how they access Spanish, what type of input they are exposed to, how much they engage with the language, 
what their motivations for learning the language are, and the way that Spanish shapes their identity. Instructed L2 learners in the US tend to be exposed to Spanish in a classroom context usually after puberty. However, these groups have in common the access to an additional linguistic system (their first language or dominant language) and the limited access to Spanish input. The comparison of these two groups allow us to explore how these different factors shape the acquisition process of these two populations and whether linguistic experience offers HSs an advantage over L2 learners, specifically in the area of morphosyntax. This will contribute to current debates in the field on the nature of linguistic knowledge (e.g., Montrul and Perpiñán 2011).

HSs might possess varying degrees of proficiency in the HL, which in turn, are associated with a series of sociological factors having to do with quality and quantity of input, degree of use of the HL, access to formal education, and the social status that the HL enjoys in their community (Stafford and Azevedo 2015). It is well-documented that HSs diverge from monolinguals and bilingual controls in a variety of linguistic domains (Montrul 2016; Pascual y Cabo 2015). In particular, some studies pointed to the fact that morphosyntax is particularly vulnerable (Pascual y Cabo 2015) and sometimes closer to that of L2 learners (Montrul 2011). Several studies concluded that, although HSs might have some advantage over L2 learners in phonetics and phonology, this advantage does not apply to the area of morphosyntax (Au et al. 2002; Knightly et al. 2003; Au et al. 2008). In contrast, other studies showed that the advantage HSs have over L2 learners does include morphosyntactic phenomena (Cuza and Frank 2015; Montrul and Perpiñán 2011). Our study contributes to this debate by examining the acquisition of a variable morphosyntactic phenomenon in these populations of speakers, which adds an extra layer of difficulty as learners have to acquire a set of constructions that alternate in the same contexts according to a series of linguistic and extralinguistic factors.

Variationist second language acquisition (SLA) is an established field with research that has examined phenomena, such as subject expression, futurity, subjunctive, and negation (among others), through a variety of methodologies, such as semi-structured interviews or the use of corpora (Gudmestad 2021). Similarly, there is a long tradition of the application of variationist methodologies to the examination of a variety of linguistic phenomena in the speech of HSs (e.g., subject expression) (Carvalho et al. 2015). Our study joins this booming field by analyzing a property that has not been previously studied within this framework (i.e., future-time expression) and by comparing HLLs' performance on a contextualized acceptability judgment task (AJT) to that of L2 learners to learn how linguistic knowledge of these two populations may differ and what factors could explain such differences.

Much of the existing research on HSs of Spanish was conducted within a generative framework. From a generative perspective, the divergences found between HSs and monolingual/bilingual controls led authors to refer to the acquisition process of HSs as incomplete acquisition (Montrul 2008) or attrition (Polinsky 2011). Pires and Rothman (2009) pointed out that we have to look at HSs' competence as the outcome of a process that is simply different from that which monolinguals undergo due to the different input that HSs receive. This line of thought pushed the field toward the inclusion of bilingual control groups. Putnam and Sánchez (2013) attributed these divergences to the different levels of activation obtained as a result of HSs' input. More recently, Giancaspro and Sánchez (2021) went a step further by focusing not on divergence but on variability; that is, how HSs alternate between two or more grammatical variants in a given context and what that tells us about their linguistic competence. From a usage-based perspective, Zyzik (2019) raised awareness about the problematic nature of the terminology used in the generative literature, such as incomplete acquisition or attrition, which can generate (unintended) negative associations. For Zyzik, this so-called incomplete acquisition could be due to the fact that certain properties remain lexically specified for HSs instead of becoming abstract as a result of the reduced amount of input. Variationist studies on HSs also problematized (e.g., Viner 2018) the use of the labels put forward to describe the HS acquisition process in earlier literature (such as incomplete acquisition, attrition, 
and simplification). They highlighted the negative connotations these terms carry, their prescriptive nature, and the impossibility of establishing the difference between attrited and non-attrited grammars, incomplete and complete grammar, or simplified and complex grammar with any precision. Instead, they studied whether linguistic or social constraints weakened or remain the same in heritage grammars, and they turned to more neutral terms, such as "different grammars", when those divergences arose. Following this tradition, our study was couched within a variationist framework and contributes to current debates on the nature of acquisition of multicompetent speakers, particularly as it relates to the acquisition of Spanish future-time expression, a variable morphosyntactic property.

\section{Background}

\subsection{Variationist Approaches to Language Acquisition}

Variationist approaches tend to analyze oral production data quantitatively, both in terms of frequency of certain linguistic forms (i.e., variants) and patterns emerging from factors that constrain usage. The focus is on forms that are variable, that is, distributions where a form is not used (near) $100 \%$ or $0 \%$ of the time, so there is a structured alternation between forms that is the object of study. The paramount morphosyntactic structure in Spanish in variationist approaches is subject expression (Carvalho et al. 2015), where data were often obtained through sociolinguistic interviews. These interviews were then transcribed and coded for the presence or absence of the subject pronoun, as well as a number of other linguistic factors (e.g., person and number, semantic verb type, priming or perseverance) and individual or societal variables (e.g., proficiency, gender, age). The coded data were then submitted to multivariate analysis (e.g., mixed-effects models) to understand the frequencies of use and the factors that significantly constrain the use of the variants.

This approach was used to examine a variety of structures (e.g., subject expression, copula selection, future-time expression) in both monolingual and multicompetent speakers. When linguistic forms are frequent, as in subject expression, open tasks where narratives are elicited are preferred (e.g., sociolinguistic interviews). Nonetheless, other types of data elicitation were successfully employed for forms that are not quite as frequent. In this paper, we used a variationist approach to examine the alternation among different forms of future-time expression in multicompetent speakers. We, however, used an AJT, which allowed us to compare how participants rated different future-time verb forms in contexts manipulated for variables that were shown in previous studies to constrain their distribution. This methodology allowed us to collect more samples across different contexts (e.g., temporal distance into the future of the event with and without a temporal adverb and also with and without certainty) and to understand multicompetent speakers' associations between the variants of future-time expression and these contexts. This knowledge, thus, can complement what we already know from corpus studies about multicompetent speakers' use of future-time expressions in production. The use of more controlled tasks comes at the risk of losing naturalness, but it is welcome in variationist approaches as "controlled tasks provide a necessary complement to corpora" (Gudmestad 2021, p. 232).

\subsection{Future-Time Expression in Monolingual Varieties}

Future-time expression is variable in Spanish where several verb forms can express future meaning. The most common variants used to express futurity are: (1) the periphrastic future (PF), (2) the morphological future (MF), and (3) the present indicative (PI). With a frequency of $70.8 \%$ across the Spanish-speaking world, the PF is considered the default marker of futurity, followed by the PI with $17.8 \%$ and the MF with $11.4 \%$ (Orozco and Thoms 2014).

(1) Voy a estudiar mañana 'I am going to study tomorrow'

(2) Estudiaré mañana 'I will study tomorrow'

(3) Estudio mañana 'I study tomorrow' 
There are other forms that encode future meaning, such as the conditional or the past subjunctive (Gutiérrez 1995). However, the present study focuses on the forms presented in (1-3), given that they are the most common forms to express futurity (Gudmestad and Geeslin 2011) and the most frequent forms studied within the variationist literature.

Studies on future-time expression in different Spanish monolingual varieties showed a clear trend: the use of the MF declining in favor of the PF and the PI (Orozco 2005, for Northern Colombian Spanish; Silva-Corvalán and Terrell 1989, for Caribbean and Chilean Spanish; Sedano 1994, for Spanish in Venezuela; Lastra and Butragueño 2010, for Spanish in Mexico). In Spain, however, this trend may not be as widely attested due to the prestige of the MF (Díaz-Peralta and Almeida 2000) or contact with other national languages (Blas Arroyo 2008).

Several linguistic factors were identified as favoring one form over the other. Here we focuse on three (certainty, temporal distance, and the presence of a temporal adverbials) that were identified as significant predictors of these variants in previous future-time expression studies.

In terms of certainty, studies in monolingual varieties showed that, while the PF is used in unmarked contexts, the MF is used where there is uncertainty (Blas Arroyo 2008; Claes and Ortiz López 2011). Certainty was also a significant factor for Gudmestad and Geeslin's (2011) native speaker (NS) control group. Specifically, when a certainty marker was present, the PF was used more often than the other two variants. With regard to temporal distance, previous research indicated that the PI is more likely to be used for immediate events, PF for intermediate events, and MF for distant events (Blas Arroyo 2008; Claes and Ortiz López 2011; Díaz-Campos and Escalona Torres 2018; Orozco 2005). Within the SLA variationist literature, Kanwit and Solon (2013) reported on two NS control groups (one from Valencia, Spain, and one from Merida, Mexico). Temporal distance was statistically significant for the Valencia speakers, as they favored PF in immediate contexts and disfavored it in the two furthest contexts. The Merida speakers showed similar trends, although temporal distance was not significant. Finally, with respect to the presence of temporal adverbs, temporal adverbials were also shown to constrain the expression of future-time verbs in Spanish. In general, the PI is favored with an adverb present and the PF and the MF when it is not. Blas Arroyo (2008) noticed that the PF tended to appear in contexts where there was no expressed adverbial. In Gudmestad and Geeslin's (2011) study, the NS control group favored the PI when a lexical temporal indicator (what we call temporal adverbials) was present and the MF and PF were favored in the absence of lexical temporal indicators. In Kanwit and Solon (2013), the presence or absence of the adverbial was not selected as significant; however, there was a clear trend associating the PI with the presence of a lexical temporal indicator.

\subsection{Future-Time Expression in L2 Learners}

Several studies examined the linguistic and social variables that impact future-time expression in L2 Spanish in classroom settings (Gudmestad and Geeslin 2011, 2013; Kanwit 2021) and study-abroad contexts (Kanwit and Solon 2013). Here we focus on the three linguistic factors that are pertinent to our study (certainty, temporal distance, and presence/absence of a temporal adverbial) and on how L2 learners diverge (or not) from NSs.

In their study comparing NSs to advanced learners of Spanish, Gudmestad and Geeslin (2011) found that certainty was a significant predictor for NSs but not the learners, which indicates that this group of highly proficient learners had not reached a nativelike level of variation. However, in a later study looking at learners at five proficiency levels (Levels 1 to 5), Gudmestad and Geeslin (2013) found that certainty was the first factor to constrain L2 learners' future-time expression in a nativelike manner, since L2 learners were able to manage the variability associated with this factor before they developed a sensitivity toward other factors, such as temporal distance or presence/absence of temporal adverbials. All groups showed higher probability of choosing the PI over the PF when a 
certainty marker was present, and all groups (except the one with the lowest proficiency) showed a higher probability of choosing the MF over the PF when a certainty marker was present. Regarding temporal distance, this variable was a significant predictor for futuretime expression for both NSs and learners in Gudmestad and Geeslin (2011). The learners used the MF in distant contexts and the PF and PI in proximate contexts, which reflected the patterns from the NS group. In Gudmestad and Geeslin (2013), all groups showed both nativelike and non-nativelike patterns with respect to temporal distance. In Kanwit and Solon (2013), this factor was only significant for the Peninsular NS group (not the Mexican one), and results from the L2 learner groups in both study-abroad contexts showed that, as their time abroad progressed, L2 learners became closer to their respective NS groups. In particular, the Peninsular L2 group showed increased sensitivity toward this variable by more strongly favoring the PF in immediate contexts and more strongly disfavoring it in the year-away contexts.

The effect of the presence or absence of a temporal adverbial in the expression of futurity is another variable we examine and that was explored in previous research. In Gudmestad and Geeslin (2011), both NSs and learners favored the PI with adverbials. Gudmestad and Geeslin (2013) argued that the use of temporal adverbials as predictors for future-time expression was the factor that took longer to develop, since just the Level 5 group (the group with the highest proficiency) presented a nativelike pattern. Both groups showed a preference for the use of the PI with temporal adverbials; they used the PF with and without adverbials and increased their selection of the MF in the absence of adverbials. In Kanwit and Solon (2013), the presence of temporal adverbials was not a predictive factor, although there is a clear trend in the use of PI when a temporal adverbial is present. Both learner groups showed sensitivity toward native norms: the Peninsular group's model did not include temporal adverbials as a factor, while the Mexican group's model included it at Time 1 but not at Time 2, showing that they were getting closer to NSs.

Overall L2 learners approached nativelike variability, although not all linguistic factors developed at the same rate. Also, studies determined that L2 learners showed the ability to adapt their grammars to converge with NS variability displayed in the communities in which they live.

\subsection{Future-Time Expression in Heritage Spanish}

The use of the PF as a default marker of futurity and the reduction of the MF to modal values was also documented in the Spanish spoken in the United States (Zentella 1997, for Spanish in the Colombian, Dominican, and Puerto Rican communities in New York City (NYC); Silva-Corvalán 1994, for Spanish in Los Angeles; Gutiérrez 1995, for Mexican Spanish in the Southwest; Orozco 2007, for Colombian Spanish in NYC; Orozco 2015 for the Spanish of Colombians and Puerto Ricans in NYC).

In this section, we focus specifically on Orozco's work as it was framed within a variationist tradition and explored some of the variables relevant for our study, in particular, temporal distance and the presence/absence of a temporal adverb. Orozco (2007) examined the expression of futurity in interviews with 20 Colombians in NYC and compared these findings to a group of speakers in Barranquilla, Colombia (Orozco 2005). In his 2015 study, he continued looking into the future-time expression of the Colombian community in NYC (corpus del español colombiano en Nueva York), as well as Puerto Rican speakers in NYC (corpus del español puertorriqueño en Nueva York), and compared these findings with data from speakers from Barranquilla, Colombia, and San Juan, Puerto Rico.

With respect to temporal distance, Orozco (2007) found that it was a significant predictor for both populations (Colombian speakers in NYC and Barranquilla), although he did not provide specific information about this variable. Orozco (2015) found that the distant future favored the MF and disfavored the PF and PI in the two groups of HSs, as well as the NSs from Barranquilla and San Juan he compared them to. Regarding temporal adverbials, Orozco (2007) also found that, for the two groups in his study, presence of a temporal adverb was a significant predictor for future expression. Orozco's (2015) 
results showed that the presence of a temporal adverb favored the PI and the MF and disfavored the PF, and this was true for speakers in NYC and the monolingual speakers in Barranquilla and San Juan. Orozco concluded that Colombian speakers of Barranquilla and NYC belonged to the same speech community, since the same factor groups were significant and the tendencies went in the same direction.

\subsection{Future-Time Expression in Textbooks and Language Pedagogy}

Orozco and Thoms (2014) explored the treatment of the expression of futurity in Spanish foreign-language textbooks. They analyzed 20 commonly used books (10 introductory and 10 intermediate) to determine (i) whether one variant (MF, PF, or PI) was emphasized over the others and (ii) whether the formal presentation of each variant accurately represented NS use. Their study confirmed that, despite the body of knowledge on NSs' expression of futurity (see Section 2.2), Spanish textbooks do not portray the reality of NS use. First, MF was the variant emphasized in Spanish textbooks, although numerous studies showed the declining use of the MF in both monolingual and bilingual populations (see Sections 2.2 and 2.4). Second, the authors compared the percentage of use of each variant in the Spanish-speaking world to its presentation in textbooks (which included formal presentation plus exercises devoted to each variant). They showed that presentation of these variants did not reflect NS usage (11\% MF, $18 \% \mathrm{PI}$, and $71 \% \mathrm{PF})$, as the MF was presented in $95 \%$ of the textbooks and $67 \%$ of exercises, the PI was presented in $65 \%$ of the textbooks and $13 \%$ of exercises, and the PF was presented in $65 \%$ of the textbooks and $20 \%$ of exercises. This study highlighted the importance of applying research on sociolinguistic variation to the development of foreign-language textbooks and underlined the current gap existing between the reality of NS usage and textbook representations.

\section{Motivation and Research Questions}

To our knowledge, no study to date has compared the acquisition of Spanish futuretime expression of HLLs and L2 learners in the same study. Including both populations in one investigation allows us to address the open question in the field related to whether differences in linguistic experience provide HLLs with an advantage over L2 learners, particularly in the area of variable morphosyntax. By means of a contextualized AJT, we tested HLLs and L2 learners' linguistic knowledge of future-time expression and present an analysis of the acquisition of this property in multicompetent speakers to understand the interplay of linguistic and social factors at stake in this process of acquisition.

In this study, we explore the following research questions (RQs):

RQ1: How do participants rate the three variants of future-time expression (PF, MF, and PI)? RQ2: What linguistic factors constrain the ratings of each variant (PF, MF, and PI) in HLLs and L2ers?

RQ3: Do ratings of the three variants (PF, MF, and PI) vary according to proficiency (based on proficiency scores) and/or speaker group (HLLs vs. L2ers)?

\section{Method}

\subsection{Participants}

A total of 54 HLLs (42 female; mean age: $21 ; S D=4.72$, range $=18-51$ ) and 42 L2 learners (32 female; mean age: $22 ; S D=2.40$, range $=19-31$ ) participated in this study. Seventeen of the HLLs were born abroad; eight of which arrived in the US when they were 8 years or older (cf. Montrul 2008) and were excluded from the analysis. The rest $(n=9)$ arrived in the US before age 8 (mean age: 5.5; range $=3-7$ ) and were included in the analysis. Also included in the analysis were six HLLs who reported being third-generation HSs, that is, those who had at least one parent born in the US or who arrived in the US before age 8, and 31 second-generation HLLs. Third-generation HLLs are excluded from other research projects, largely due to their inability to use Spanish, which was not the case for the third-generation HLLs in this study. Generation was not included in our analysis or used to justify exclusion from the analysis because classification into generations 
could blur some differences (e.g., were those third-generation participants who lived with a Spanish-speaking grandparent during childhood the same as those who did not). The HLLs represented a wide variety of Spanish varieties (Colombia, Cuba, Dominican Republic, Panama, Puerto Rico, Salvador, Spain, Venezuela, etc.). All the L2 learners acquired Spanish in a classroom setting, and all except for six participants started acquiring Spanish between the ages of 11 and 18. Those six participants began acquiring Spanish in a formal setting at ages $5(n=2), 7(n=1), 8(n=2)$, and $9(n=1)$. In the end, the analysis included 46 HLLs (36 female; mean age: $20, S D=2.30$, range $=18-26$ ) and 42 L2 learners.

Even though both participant groups were university students in Spanish courses at the time of data collection, they differed in the age and context of acquisition of Spanish: HLLs were exposed to Spanish in the home at an early age, while the L2 learners were exposed to it in the classroom. With respect to childhood acquisition of the future-time reference, children from Madrid in Kanwit (2013) showed evidence of use of the MF in the earliest group ( 3 year olds), but it was used very rarely until age 6. In all age groups, though, the PF was the most frequent form used $(81.9 \%$ vs. $18.1 \%$ use of the MF). Thus, the HLLs were likely exposed to all three verb forms in their childhood before they were explained in their Spanish classes. The L2 learners, on the other hand, were first exposed through textbooks and grammar explanations in the classroom setting, with the different representations of these forms, as compared to monolingual NS norms ${ }^{2}$, detailed in Orozco and Thoms (2014).

With respect to proficiency (from a 50-item section of the Diploma de Español como Lengua Extranjera [DELE], cf. Section 4.2 for more details), 10 HLLs scored within the advanced (40-50/50), 14 within the intermediate (30-39/50), and 22 within the low proficiency range (0-29/50). As for the L2 learners, 6 scored within the advanced, 16 within the intermediate, and 20 within the low proficiency range. A two-sided t-test revealed that the HLLs (mean $=31 / 50, S D=8.34)$ and the L2 learners (mean $=29 / 50, S D=8.43$ ) were of comparable proficiency $(t(85)=1.124, p=0.264)$. Participants were also asked to self-report their proficiency level on a 7 -point scale $(1=$ minimum ability, $7=$ nativelike ability), which revealed that most HLLs rated their English higher than their Spanish, except for 11 who rated both at 7. Similarly, all the L2 learners rated their English higher than their Spanish, except for one who rated both at 7. In the analyses, only the results from the DELE task were used. A summary of additional participant data regarding language use and immersion is included in Table 1.

Table 1. Participant background information.

\begin{tabular}{|c|c|c|}
\hline & HLLs & L2 Learners \\
\hline $\begin{array}{l}\text { Time in } \\
\text { Spanish-speaking country }\end{array}$ & $\begin{array}{l}\text { None }(n=28) \\
\text { Less than a year }(n=4) \\
\text { Multiple brief visits throughout } \\
\text { life }(n=1) \\
\text { Multiple years }(n=13)\end{array}$ & $\begin{array}{l}\text { None }(n=33) \\
\text { Less than a year }(n=6) \\
\text { One year }(n=2) \\
\text { Two years }(n=1)\end{array}$ \\
\hline Spanish usage & $\begin{array}{l}\text { Every day, most of day }(n=7) \\
\text { Every day, sporadically }(n=17) \\
\text { Few times a week }(n=14) \\
\text { Once per week }(n=7) \\
\text { Once or twice a month }(n=1)\end{array}$ & $\begin{array}{l}\text { Every day, most of day }(n=6) \\
\text { Every day, sporadically }(n=13) \\
\text { Few times a week }(n=21) \\
\text { Once per week }(n=1) \\
\text { Once or twice a month }(n=1)\end{array}$ \\
\hline English usage & $\begin{array}{l}\text { Every day, most of day }(n=44) \\
\text { Every day, sporadically }(n=2)\end{array}$ & $\begin{array}{l}\text { Every day, most of day }(n=38) \\
\text { Every day, sporadically }(n=2) \\
\text { Few times a week }(n=2)\end{array}$ \\
\hline
\end{tabular}

\subsection{Data Collection and Coding}

Participants completed a language background questionnaire, a proficiency test, and an untimed contextualized written AJT via Qualtrics. The background questionnaire elicited demographic information related to gender, age, age of acquisition, language dominance, self-reported language use, self-ratings of proficiency, and motivation for learn- 
ing Spanish. The proficiency test was an abbreviated version of the DELE (Montrul and Slabakova 2003) and included a multiple-choice vocabulary section and a cloze grammar test. In the contextualized AJT, we manipulated contexts for three independent linguistic variables: certainty (+/ - certain), temporal distance (close and distant), and presence of a temporal adverbial (with or without adverb). For certainty, the context was manipulated to indicate certainty (4) or uncertainty (5).

(4) Juan ha planeado su fin de semana a la perfección. Le cuenta a Pedro sus planes para el fin de semana. 'Juan has planned his weekend to perfection. He told Pedro about his plans.'

(5) Vero le pregunta a Julio dónde piensa trabajar en 5 años. Aunque él realmente no lo sabe, responde. 'Vero asks Julio where he is thinking of working in 5 years. Although he doesn't really know, he responds.'

In (4), the plans have been made, so there is no uncertainty about what the plans are, while in (5), Julio does not know yet, so there is uncertainty expressed in the context. For temporal distance, the context referred to either a close future (esta tarde 'this afternoon/evening', mañana 'tomorrow', or este fin de semana 'this weekend') or a distant future (en un año 'in one year', en cinco años 'in five years', en diez años 'in ten years'). For the presence of a temporal adverb, the target sentences included one of the temporal markers for close or distant future or it did not. After reading each context, participants had three possible follow-up sentences with PF, MF, and PI. This design allowed us to test if HLLs and L2 learners in our study were sensitive to the factors of certainty, temporal distance, and the presence of a temporal adverbial and whether the direction of the effects was similar to those previously reported in the literature. In particular, to be comparable to monolingual or bilingual NSs in previous studies, we anticipated an interaction between each of these factors and the factor verb form, where participants would rate MF higher with contexts coded as uncertain, distant, and without an adverb. The PF would be rated higher with contexts that were certain, distant, and without a temporal adverb. The PI would be rated higher with contexts that were certain, temporally close, and with the presence of a temporal adverb. For every item, participants rated each of the three responses on a 4-point Likert scale ( 1 = completely unacceptable, $4=$ completely acceptable). The combination of these three variables yielded eight different conditions with six items per condition, which resulted in a total of 48 critical items. Forty-eight fillers dealing with subject expression were also included as part of the questionnaire. The conditions are provided in Table 2.

Table 2. Experimental conditions.

\begin{tabular}{cc}
\hline Condition A & Condition E \\
Doubt, close, no adverb & No doubt, close, no adverb \\
[-certain] [+close] [-adverb] & [+certain] [+close] [-adverb] \\
Condition B & Condition F \\
Doubt, close, adverb & No doubt, close, adverb \\
[-certain] [+close] [+adverb] & [+certain] [+close] [+adverb] \\
Condition C & Condition G \\
Doubt, distant, no adverb & No doubt, distant, no adverb \\
[-certain] [-close] [-adverb] & [+certain] [-close] [-adverb] \\
Condition D & Condition H \\
Doubt, distant, adverb & No doubt, distant, adverb \\
[-certain] [-close] [+adverb] & [+certain] [-close] [+adverb] \\
\hline
\end{tabular}

In (6), we have an example of a context from Condition A [-certain] [+close] [-adverb].

(6) Condition A sample question

Javier le pregunta a su hijo qué tiene que hacer por la tarde después del colegio. El chico, aunque todavía no lo sabe con seguridad, contesta:

'Javier asks his son what he has to do in the evening after school. The boy, although he does not know for sure, replies': 
a. Voy al jugar al fútbol 'I am going to play soccer' 1234

b. Jugaré al fútbol 'I will play soccer' 1234

c. Juego al fútbol 'I play soccer' 1234

We controlled for the following features: clause type (all were main clauses), person (all items were first person), negation (all sentences were affirmative), and verb type (all verbs were activities) to avoid introducing variability, since previous research reported that these features can have an effect. All tokens were randomized and counterbalanced. The instrument used in this study can be found in Appendix A.

\subsection{Data Analysis}

The dependent variable in this study was the rating of each of the response sentences (from $1=$ totally unacceptable to $4=$ totally acceptable). This was in contrast to previous studies on speaker production, which analyzed verb form (PI, PF, and MF) as the dependent variable. The importance of verb form, though, remained crucial in this study in that its interactions with the other independent variables were essential for understanding the effects of the rest of the variables. For example, the effect of temporal distance on a sentence rating was only relevant to our purpose in relation to verb form. We did not have predictions for participants to rate sentences in a distant future higher than sentences in a close future per se. However, we did have predictions for the ratings of the MF in a distant vs. a close future (i.e., the interaction between verb form and temporal distance). Similarly, we anticipated an interaction between verb form and certainty, where the MF would be rated higher with uncertainty, the PI with certainty, and the PF similarly with uncertainty and certainty, and an interaction between verb form and the presence of a temporal adverb, in that only the PI would be favored with a temporal adverb.

Ratings from the AJT were analyzed in R (R Core Team 2017), fitting cumulative link mixed-effects models with a specified probit link function using the clmm function in the package ordinal (Christensen 2019). This analysis was selected given the ordinal nature of the ratings on the Likert scale and the option to include random factors in the analysis. The default option of flexible thresholds between each Likert value was set to accommodate the fact that the probability of choosing one rating value over another may not be equal across the scale. In this AJT, for instance, participants may not perceive the distance between a 3 (acceptable) and a 4 (totally acceptable) as the same between a 2 (unacceptable) and a 3 (acceptable). Model selection was carried out using the buildmer package (Voeten 2020), which finds the maximally converging model and performs backward stepwise elimination based on changes in log-likelihood ratios from nested model comparisons. The analysis began with the fixed effects (dummy coded) of verb form (PI, PF, and MF), certainty (doubt, no doubt), temporal distance (close or distant event), temporal adverb (present, absent), speaker group (HLL, L2 learner), and proficiency (mean-centered, based on the DELE test score), as well as all interactions, and random intercepts of participant and item ${ }^{3}$.

\section{Results}

In this section, we first report on the results of the model obtained from the inclusion of both groups in the analysis, followed by two analyses where each of the groups were analyzed separately.

The results of the final model (see Appendix B) revealed several three-way interactions involving the variable speaker group. Speaker group interacted with verb form and adverb, verb form and certainty, verb form and proficiency, certainty and temporal distance, as well as temporal distance and adverb. This suggests that the significance or magnitude and direction of interactions with verb form may have differed between the HLLs and the L2 learners. To better understand these interactions, the data was split by speaker group, and the same model selection procedure with the same variables was followed for each of the groups. 


\subsection{HLLs}

The final equation for the HLLs selected through the buildmer package included the fixed effects of verb form, certainty, temporal distance, adverb, and proficiency; as well as the two-way interactions between verb form and all the other fixed effects: certainty and temporal distance, certainty and proficiency, and, lastly, temporal distance and adverb; and random intercepts of participant and item. The equations are found in Appendix C. Figure 1 shows mean ratings per condition. As can be observed, the PI received the lowest ratings of the three variants in all conditions, while the $\mathrm{PF}$ and the MF received higher ratings. In contexts of certainty, the PF was numerically higher than the MF, while the MF was numerically higher than the PF in contexts of uncertainty. The PI received the highest rating in the condition with a close future context with certainty and a temporal adverb present; interestingly, that was the condition where the MF received the lowest rating, with similar ratings in other conditions. The $\mathrm{PF}$ also received higher ratings, which were similar numerically across conditions, with higher ratings in contexts of certainty than contexts of uncertainty.

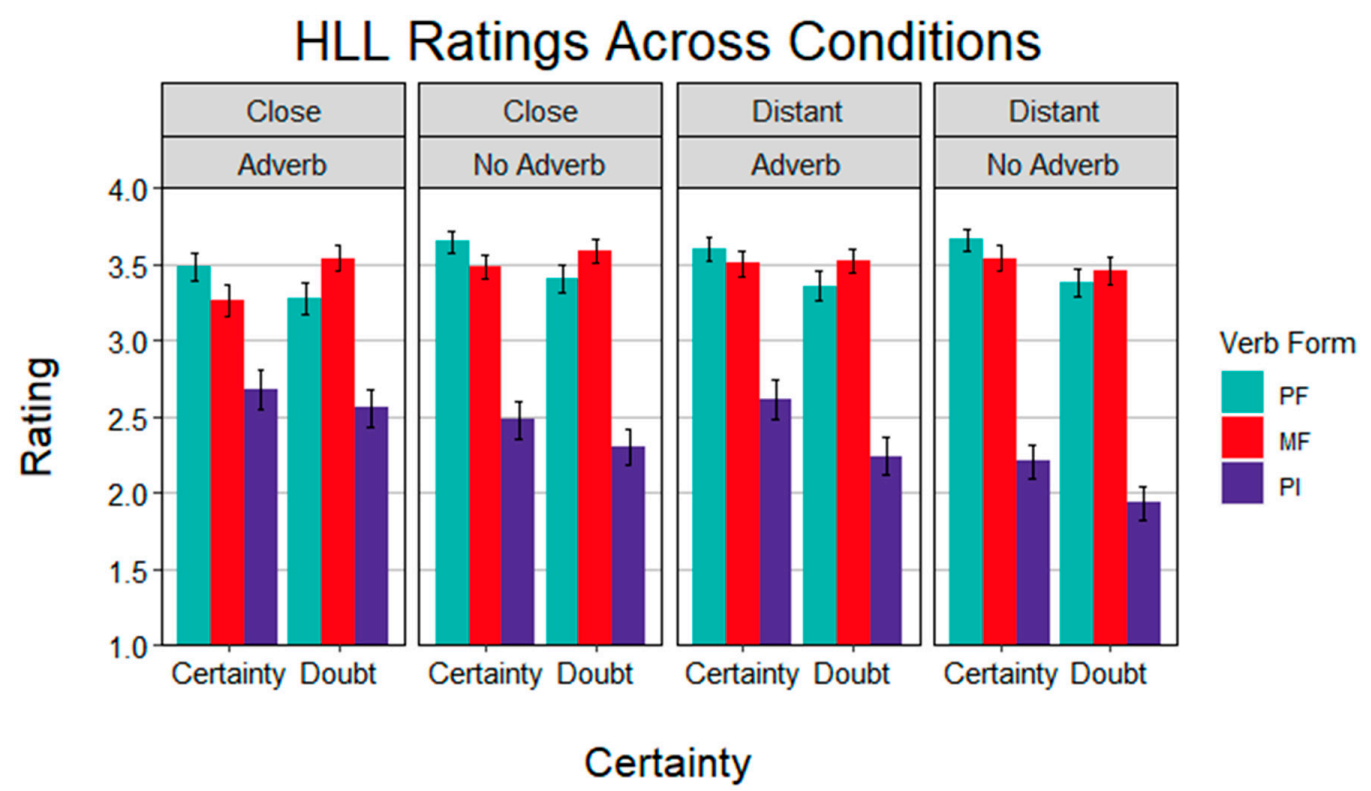

Figure 1. Average HLL sentence ratings with $95 \%$ confidence interval bars.

The results from the cumulative link mixed-effects model indicated that there were significant effects for verb form, proficiency, certainty, and temporal distance, as well as significant interactions of verb form $\mathrm{x}$ certainty, proficiency $\mathrm{x}$ certainty, verb form $\mathrm{x}$ proficiency, verb form $x$ temporal distance, certainty $x$ temporal distance, verb form $x$ adverb, and temporal distance $x$ adverb (see Appendix $\mathrm{D}$ for the final model table).

To better understand these interactions, a series of pairwise comparisons were run using the emmeans package (Lenth 2020) and the functions emmeans for nominal variables and emtrends for the continuous variable (proficiency). These analyses allowed us to see where there were interactions and to identify the specific combination of features that was giving rise to the interaction between the two factors. For example, in an interaction between verb form and certainty, these analyses allowed us to see (i) whether there was a verb form effect in each of the certainty contexts (i.e., was one of the variants (MF, PF, or PI) rated higher than the other variants in contexts of certainty?) and (ii) whether there was a certainty effect for each of the verb forms (i.e., were the MF, PF, and PI rated higher in contexts of certainty than uncertainty or vice versa?). 
With respect to the interaction of verb form and certainty, the results indicated that there were significant differences in the ratings among the three verb forms both in contexts of certainty and uncertainty. Specifically, the results revealed that, in contexts of certainty, the ratings of the PI were likely to be significantly lower than those of the MF $(\beta=-1.265$, $S E=0.050, z=-25.082, p<0.001)$ and PF $(\beta=-1.561, S E=0.053, z=-29.522, p<0.001)$ and that the PF was likely to be rated higher than the MF $(\beta=0.296, S E=0.054, z=5.513$, $p<0.001)$. In contexts of doubt, however, the MF was likely to be rated significantly higher than both the PF $(\beta=0.295, S E=0.052, z=5.713, p<0.001)$ and the PI $(\beta=1.681, S E=0.052$, $z=32.394, p<0.001)$, and the PF was more likely to be rated higher than the PI $(\beta=1.386$, $S E=0.050, z=27.776, p<0.001)$. Thus, the PI was likely to be rated lowest in both contexts, but the PF was likely to be rated highest in contexts of certainty and the MF in contexts of doubt. Additionally, the results revealed significant differences in the effect of the variable certainty in all three verb forms. While the MF was more likely to be rated higher in contexts of doubt than in contexts of certainty (MF: $\beta=-0.135, S E=0.058, z=-2.335$, $p=0.020)$, the PF and PI were more likely to be rated higher in contexts of certainty than doubt (PF: $\beta=0.457, S E=0.058, z=7.815, p<0.001 ; \mathrm{PI}: \beta=0.282, S E=0.053, z=5.355$, $p<0.001)$.

With respect to the interaction between verb form and temporal distance, the results indicated that there were significant differences in the ratings among the three verb forms both with close and distant events. In particular, the results revealed that the PF and MF were likely to be rated similarly for both close $(\beta=-0.009, S E=0.052, z=-0.180, p=0.857)$ and distant $(\beta=0.011, S E=0.053, z=0.200, p=0.842)$ events and significantly higher than the PI for both close (PF: $\beta=1.280, S E=0.051, z=25.342, p<0.001$; MF: $\beta=1.290$, $S E=0.051, z=25.557, p<0.001)$ and distant (PF: $\beta=1.667, S E=0.052, z=31.951, p<0.001$; MF: $\beta=1.656, S E=0.052, z=31.980, p<0.001)$ events. Additionally, there were differences between the three verb forms in whether there was a temporal distance effect. The effect of temporal distance was not significant for the $\operatorname{MF}(\beta=0.067, S E=0.058, z=1.157, p=0.247)$ or PF $(\beta=0.087, S E=0.058, z=1.497, p=0.135)$, but it was for the PI $(\beta=-0.299, S E=0.052$, $z=-5.744, p<0.001)$, where the rating was likely to be higher in close than in distant events.

Lastly, regarding the interaction between verb form and the presence of a temporal adverbial, similar contrasts in ratings among the three verb forms emerged. Specifically, the results showed that the PF and MF were likely to be rated similarly with an adverb $(\beta=-0.031, S E=0.052, z=-0.592, p=0.554)$ and without it $(\beta=0.032, S E=0.053, z=0.597$, $p=0.551)$, and both forms were likely to be significantly higher than the PI, in contexts both with an adverb (PF: $\beta=1.214, S E=0.050, z=24.195, p<0.001 ; \mathrm{MF}: \beta=1.245, S E=0.050$, $z=24.766, p<0.001$ ) and without an adverb (PF: $\beta=1.733, S E=0.053, z=33.003, p<0.001$; MF: $\beta=1.701, S E=0.052, z=32.711, p<0.001)$. Additionally, there were differences between the three verb forms in whether there was an effect of the presence of a temporal adverb. The presence of the adverb was not significant for the $\operatorname{MF}(\beta=-0.107, S E=0.058$, $z=-1.845, p=0.065)$. In contrast, the PF was likely to be rated higher in sentences without an adverb than with one $(\beta=-0.169, S E=0.058, z=-2.915, p=0.004)$, and the PI was more likely to be rated higher in sentences with an adverb than without one $(\beta=0.349$, $S E=0.053, z=6.638, p<0.001)$.

Proficiency modulated the variables certainty and verb form. Of more relevance for our study was the interaction between proficiency and verb form, which showed that, as proficiency increased, so did the acceptance of the PF $(\beta=0.023, S E=0.009, z=2.647$, $p=0.008)$ and the MF $(\beta=0.020, S E=0.009, z=2.298, p=0.022)$, but not the PI $(\beta=0.005$, $S E=0.009, z=0.574, p=0.566)$. For the HLLs of average proficiency, the ratings for the $\mathrm{PF}$ and MF were similar $(\beta=0.001, S E=0.037, z=0.016, p=0.988)$ and higher than the ratings for the PI (PF: $\beta=1.474, S E=0.037, z=39.358, p<0.001 ; \mathrm{MF}: \beta=1.473, S E=0.037$, $z=39.540, p<0.001)$. 


\subsection{L2 Learners}

The final equation selected by the buildmer package with the L2 learner data included all the fixed effects (verb form, certainty, temporal distance, presence of a temporal adverb, and proficiency); all the two-way interactions involving verb form; two-way interactions between proficiency and certainty and between proficiency and temporal distance; and three-way interactions between verb form, temporal distance, and proficiency, as well as verb form, temporal distance, and proficiency; and random intercepts of participant and item. These fixed effects, interactions, and random intercepts were, thus, included in the cumulative link mixed-effects model (see equation in Appendix E). Figure 2 shows mean ratings per condition. As can be observed, for the L2 learners, the PI received the lowest ratings of the three variants in all conditions, while the PF and MF received higher ratings. The PF and MF were rated quite similarly. Nonetheless, the PF was slightly higher than the MF in close future contexts (but not with uncertainty and a temporal adverb). In distant future contexts, the MF was slightly higher than the PF in certain contexts without an adverb, and the PF was slightly higher than the MF in contexts of doubt without an adverb. The PI was rated highest in close contexts and with a temporal adverb. In contrast, the MF was rated lower in that condition. The PF seemed to have consistently high ratings across conditions.

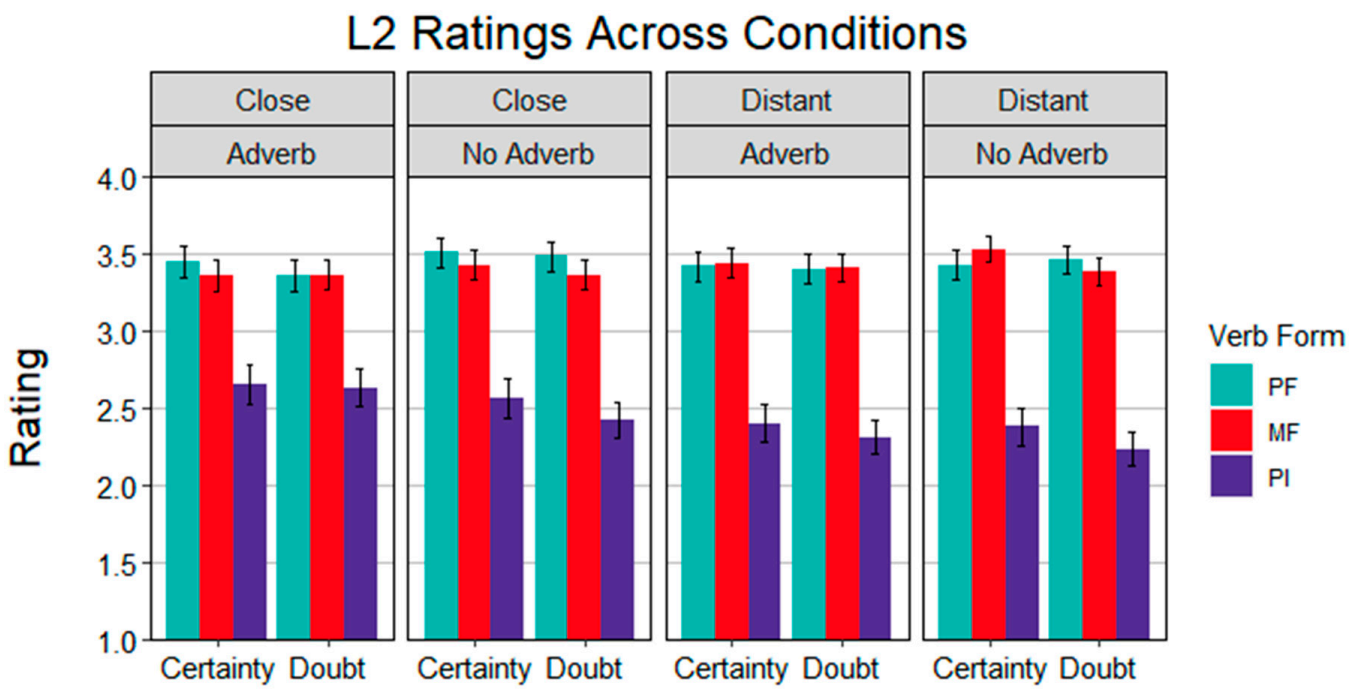

\section{Certainty}

Figure 2. Average L2 sentence ratings with $95 \%$ confidence interval bars.

The results from the cumulative link mixed-effects model, carried out subsequent to the model selection and summarized in Appendix F, indicated that there were significant effects for verb form, proficiency, and temporal adverb, as well as significant interactions of verb form $\mathrm{x}$ temporal distance, verb form $\mathrm{x}$ temporal adverb, and verb form $\mathrm{x}$ proficiency $\mathrm{x}$ certainty and marginal interactions of verb form $\mathrm{x}$ proficiency and verb form $\mathrm{x}$ proficiency $\mathrm{x}$ temporal distance.

Pairwise comparisons were carried out following the same methods as the HLLs. Recall that for each interaction, we received information on (i) contrasts between the three verb forms in each context (i.e., close vs. distant future, certain vs. uncertain context, presence vs. absence of a temporal adverb) and (ii) contrasts between the contexts in each of the three verb forms.

Regarding the interaction between verb form and the presence of a temporal adverb, the results indicated that there were significant differences in the ratings among the three verb forms, both with an adverb and without it. Specifically, the results indicated that the PF and MF were likely to be rated significantly higher than the PI form, both with 
adverbs (PF: $\beta=1.280, S E=0.053, z=24.329, p<0.001 ; \mathrm{MF}: \beta=1.238, S E=0.052, z=23.717$, $p<0.001$ ) and no adverbs (PF: $\beta=1.521, S E=0.054, z=28.287, p<0.001$; MF: $\beta=1.411$, $S E=0.053, z=26.738, p<0.001)$. The PF form was likely to be rated higher than the MF with no adverb $(\beta=0.109, S E=0.055, z=1.999, p=0.046)$ but similarly with an adverb $(\beta=0.041, S E=0.054, z=0.763, p=0.445)$. Additionally, the results indicated that there were differences between the three verb forms in whether the presence of the adverb had an effect. In particular, the effect of the presence of the adverb was not significant for the MF $(\beta=-0.052, S E=0.055, z=-0.932, p=0.351)$, but it was for the PF $(\beta=-0.120, S E=0.056$, $z=-2.125, p=0.034)$ and the PI $(\beta=0.121, S E=0.050, z=2.427, p=0.015)$, with different direction of effects. The PF was likely to be rated higher without an adverb than with an adverb, and the PI was likely to be rated higher with an adverb than without it.

All other interactions involved the variable proficiency. The interaction of verb form $x$ proficiency $x$ temporal distance (Figure 3) indicated that, as proficiency score increased, the PF was likely to be rated higher both in close future $(\beta=0.032, S E=0.011, z=2.828$, $p=0.005)$ and distant future contexts $(\beta=0.031, S E=0.011, z=2.707, p=0.007)$, as seen in the upward trajectories of the blue lines. Rating likelihoods for all other verb form $x$ temporal distance pairings did not significantly change with increases in proficiency (all $p$ values were $>0.068$ ). For learners of average proficiency, the PF and MF were likely to be rated higher than the PI in close (PF: $\beta=1.276, S E=0.053, z=24.011, p<0.001$; MF: $\beta=1.117$, $S E=0.052, z=21.560, p<0.001)$, as well as in distant (PF: $\beta=1.524, S E=0.053, z=28.575$, $p<0.001$; MF: $\beta=1.532, S E=0.053, z=28.782, p<0.001)$ future contexts. The PF was also more likely to be rated higher than the MF in close future contexts $(\beta=0.159, S E=0.054$, $z=2.924, p=0.004)$, whereas there was no difference in distant contexts $(\beta=-0.008$, $S E=0.055, z=-0.149, p=0.882$ ).

To examine whether these differences hold across proficiency levels, we recentered proficiency scores based on quartiles (Q1: 25th percentile on lower end, Q3: 75th percentile on upper end). This revealed similar patterns to the average-centered proficiency analysis. Specifically, the PF was likely to be rated higher than the PI in close contexts (Q1: $\beta=1.212$, $S E=0.061, z=19.760, p<0.001 ; \mathrm{Q} 3: \beta=1.331, S E=0.062, z=21.449, p<0.001)$, as well as in distant contexts (Q1: $\beta=1.380, S E=0.061, z=22.485 ; p<0.001 ; \mathrm{Q} 3: \beta=1.649, S E=0.062$, $z=26.548, p<0.001)$. Similarly, the MF was likely to be rated higher than the PI in close (Q1: $\beta=1.243, S E=0.062, z=20.127, p<0.001 ; \mathrm{Q} 3: \beta=1.009, S E=0.059, z=17.169, p<0.001)$ and distant $(\mathrm{Q} 1: \beta=1.498, S E=0.062, z=24.056, p<0.001 ; \mathrm{Q} 3: \beta=1.562, S E=0.061$, $z=25.623, p<0.001)$ contexts. Additionally, the PF and MF were rated similarly at lower and higher levels of proficiency in distant contexts (Q1: $\beta=-0.119, S E=0.063, z=-1.876$, $p=0.061$; Q3: $\beta=0.087, S E=0.064, z=1.360, p=0.174)$. In close future contexts, however, the PF was rated higher than the MF at higher but not lower levels of proficiency (Q1: $\beta=-0.032, S E=0.063, z=-0.500 ; p=0.617 ; \mathrm{Q} 3: \beta=0.322, S E=0.063, z=5.096, p<0.001$ ).

Additionally, comparisons of temporal distance for each verb form revealed differences based on proficiency. The PI was likely to be rated higher in close than future distant contexts $(\beta=0.295, S E=0.050, z=5.909, p<0.001)$, and this increased with proficiency (Q1: $\beta=0.207, S E=0.059, z=3.531, p<0.001 ; \mathrm{Q} 3: \beta=0.371, S E=0.057, z=6.514, p<0.001)$. The MF was likely to be rated higher in distant than in close contexts $(\beta=0.120, S E=0.055$, $z=2.169, p=0.030)$, but this finding was not present at lower proficiency levels (Q1: $\beta=0.048, S E=0.065, z=0.734, p=0.463 ; \mathrm{Q} 3: \beta=0.182, S E=0.063, z=2.887, p=0.004)$. Finally, the PF was rated similarly between close and distant contexts $(\beta=0.047, S E=0.057$, $z=0.828, p=0.408)$, and this held across proficiency levels $(\mathrm{Q} 1: \beta=0.039, S E=0.064$, $z=0.610, p=0.542$; Q3: $\beta=0.053, S E=0.067, z=0.801, p=0.423$ ). 


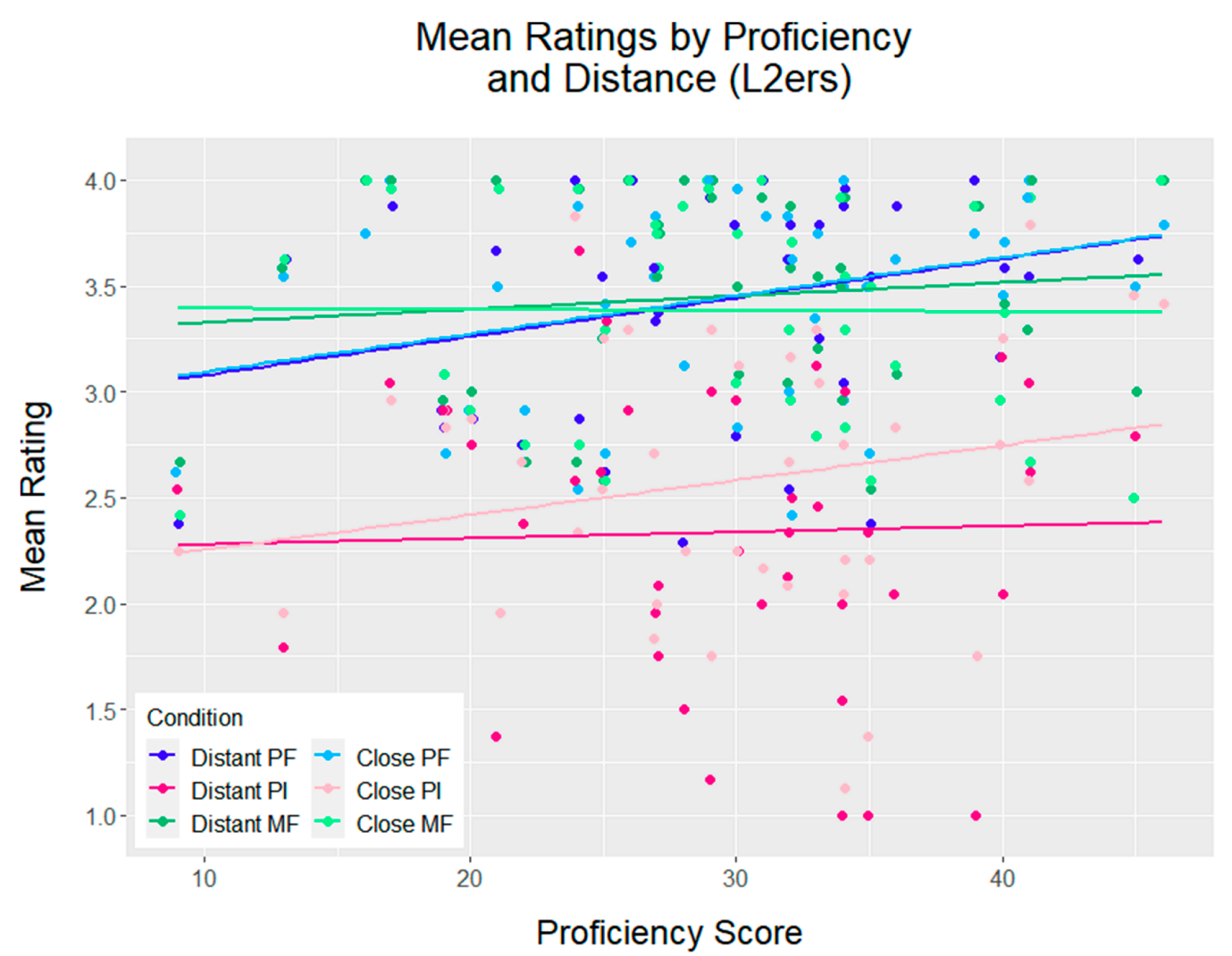

Figure 3. Proficiency and mean ratings by verb form and temporal distance.

The interaction of verb form $x$ proficiency $x$ certainty (Figure 4) indicated that as proficiency score increased, the rating for the PF was likely to be rated higher, both in contexts of certainty $(\beta=0.033, S E=0.011, z=2.858, p=0.004)$ and doubt $(\beta=0.030$, $S E=0.011, z=2.678, p=0.007)$, as seen by the upward trajectories of the blue lines. Similarly, as proficiency increased, the PI was likely to be rated higher in contexts of certainty $(\beta=0.026, S E=0.011, z=2.361, p=0.018)$, as shown by the dark pink line. Rating likelihoods for all other verb form $x$ certainty pairings did not significantly change with increases in proficiency ( $p$ values $>0.326$ ). For learners of average proficiency, the PF and MF were likely to be rated higher than the PI in contexts of certainty (PF: $\beta=1.358$, $S E=0.053, z=25.414, p<0.001$; MF: $\beta=1.318, S E=0.053, z=24.919, p<0.001)$ and contexts of doubt (PF: $\beta=1.443, S E=0.053, z=27.197, p<0.001$; MF: $\beta=1.332, S E=0.052, z=25.540$, $p<0.001)$. The PF was also more likely to be rated higher than the MF in contexts of doubt ( $\beta=0.111, S E=0.054, z=2.059, p=0.040)$, whereas there was no difference in contexts of certainty $(\beta=0.040, S E=0.055, z=0.722, p=0.470)$. 


\section{Mean Ratings by Proficiency and Certainty (L2ers)}

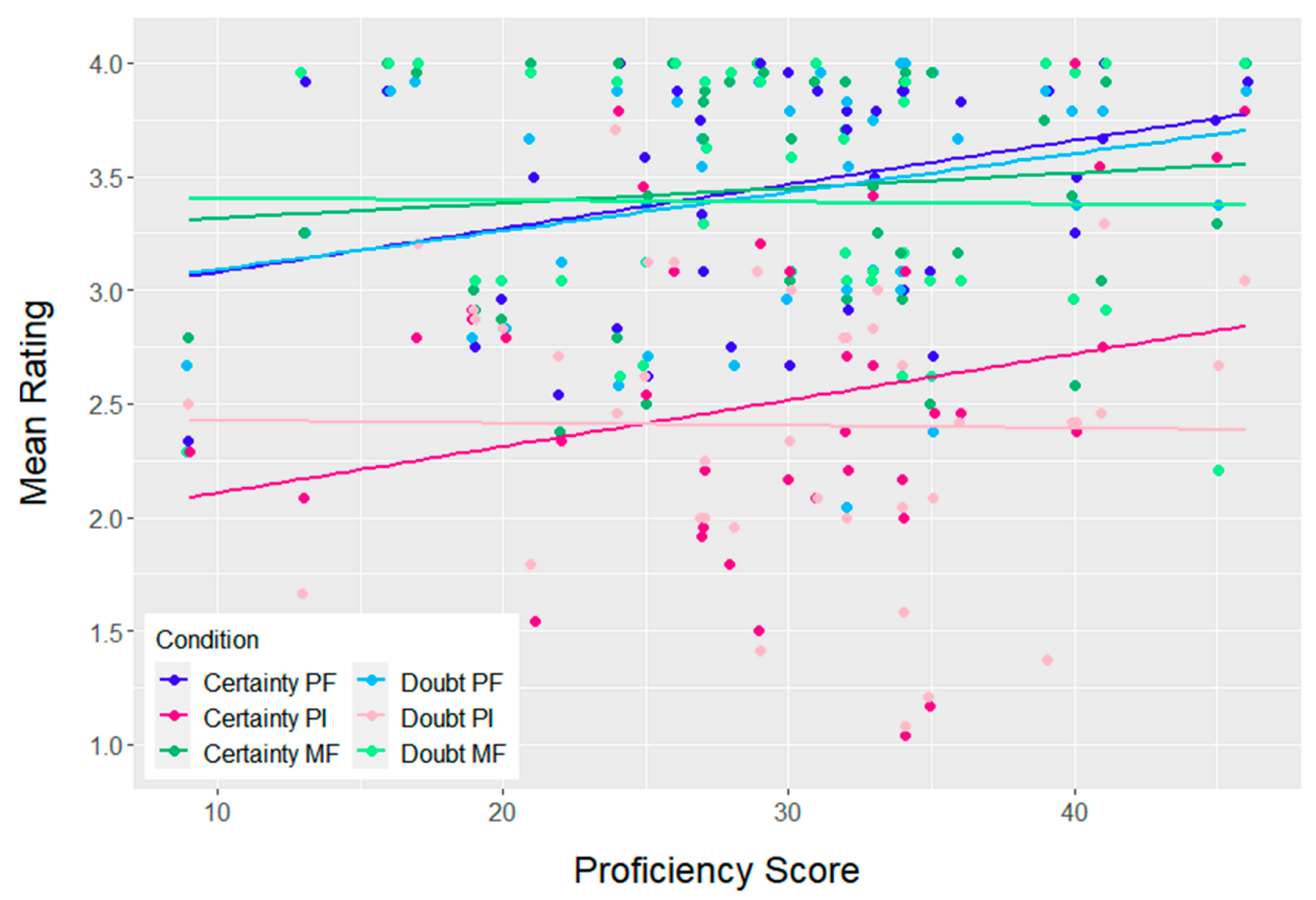

Figure 4. Proficiency and mean ratings by verb form and certainty.

To examine these effects across proficiency levels, we recentered proficiency based on quartiles. This revealed that the PF was likely to be rated higher than the PI across proficiency levels, both in contexts of certainty (Q1: $\beta=1.324, S E=0.062, z=21.487$, $p<0.001$; Q3: $\beta=1.387, S E=0.062, z=22.217, p<0.001$ ), as well as in contexts of doubt (Q1: $\beta=1.267, S E=0.061, z=20.757, p<0.001 ; \mathrm{Q} 3: \beta=1.593, S E=0.062, z=25.804$, $p<0.001)$. Similarly, the MF was likely to be rated higher than the PI across proficiency levels, both in contexts of certainty $(\mathrm{Q} 1: \beta=1.400, S E=0.062, z=22.569, p<0.001$; $\mathrm{Q} 3$ : $\beta=1.248, S E=0.061, z=20.567, p<0.001)$ and $\operatorname{doubt}(\mathrm{Q} 1: \beta=1.342, S E=0.062, z=21.629$, $p<0.001 ; \mathrm{Q} 3: \beta=1.323, S E=0.059, z=22.423, p<0.001$ ). Additionally, the PF and MF were rated similarly at lower proficiency levels, while the PF was likely to be rated higher than the MF at higher proficiency levels. This pattern was found both in contexts of certainty $(\mathrm{Q} 1: \beta=-0.076, S E=0.064, z=-1.196, p=0.232 ; \mathrm{Q} 3: \beta=0.139, S E=0.064, z=2.155$, $p=0.031)$, as well as doubt (Q1: $\beta=-0.075, S E=0.063, z=-1.178, p=0.239 ; \mathrm{Q} 3: \beta=0.270$, $S E=0.063, z=4.311, p<0.001$.

Comparisons of certainty for each verb form revealed differences based on proficiency. The PI was likely to be rated higher in contexts of certainty than $\operatorname{doubt}(\beta=0.131, S E=0.050$, $z=2.611, p=0.009)$, but this was not present at lower levels of proficiency $(\mathrm{Q} 1: \beta=-0.023$, $S E=0.059, z=-0.386, p=0.699 ; \mathrm{Q} 3: \beta=0.262, S E=0.057, z=4.603, p<0.001)$. The MF was likely to be rated higher in contexts of certainty than doubt $(\beta=0.117, S E=0.055, z=2.114$, $p=0.035)$, but this was not present at lower levels of proficiency $(\mathrm{Q} 1: \beta=0.036, S E=0.065$, $z=0.545, p=0.586$; Q3: $\beta=0.187, S E=0.063, z=2.965, p=0.003$ ). Finally, the PF was rated similarly between contexts of certainty and doubt $(\beta=0.046, S E=0.057, z=0.807, p=0.420)$, and this held across proficiency levels (Q1: $\beta=0.034, S E=0.064, z=0.531, p=0.596$; Q3: $\beta=0.056, S E=0.067, z=0.834, p=0.404)$. 


\subsection{Summary of Results}

Table 3 offers a summary of the interactions between verb form and each of the other fixed effects from the AJT ratings for both speaker groups.

Table 3. Summary of results.

\begin{tabular}{|c|c|c|c|c|c|c|}
\hline \multirow{3}{*}{$\begin{array}{c}\text { Fixed Effects } \\
\text { Verb Form } \\
\text { Certainty }\end{array}$} & \multicolumn{3}{|c|}{ HLLs } & \multicolumn{3}{|c|}{ L2 Learners } \\
\hline & PF & MF & PI & PF & MF & PI \\
\hline & $\begin{array}{l}\text { Certainty }> \\
\text { Doubt }\end{array}$ & $\begin{array}{l}\text { Doubt }> \\
\text { Certainty }\end{array}$ & $\begin{array}{c}\text { Certainty }> \\
\text { Doubt }\end{array}$ & \multicolumn{3}{|c|}{ Three-way interaction with proficiency } \\
\hline $\begin{array}{l}\text { Temporal } \\
\text { distance }\end{array}$ & Close $=$ Distant & Close $=$ Distant & Close $>$ Distant & \multicolumn{3}{|c|}{ Three-way interaction with proficiency } \\
\hline Adverb & Absent $>$ Present & Absent $=$ Present & Present $>$ Absent & Absent $>$ Present & Absent $=$ Present & Present > Absent \\
\hline $\begin{array}{l}\text { Contrasts by } \\
\text { Proficiency }\end{array}$ & $\mathrm{N} / \mathrm{A}$ & N/A & N/A & $\begin{array}{l}\text { Close = Distant, } \\
\text { Certainty = Doubt } \\
\text { at higher and lower } \\
\text { levels of proficiency }\end{array}$ & $\begin{array}{c}\text { Distant }>\text { Close, } \\
\text { Certainty }>\text { Doubt } \\
\text { only at higher } \\
\text { proficiency }\end{array}$ & $\begin{array}{c}\text { Close }>\text { Distant } \\
\text { (larger effect at } \\
\text { higher proficiency), } \\
\text { Certainty }>\text { Doubt } \\
\text { (only at higher } \\
\text { proficiency) }\end{array}$ \\
\hline $\begin{array}{l}\text { Proficiency } \\
\text { simple effect }\end{array}$ & \multicolumn{3}{|c|}{ MF and PF ratings increased with proficiency } & $\begin{array}{l}\text { PF ratings increase } \\
\text { with proficiency in } \\
\text { Certainty, Doubt, } \\
\text { Close, and Distant } \\
\text { contexts }\end{array}$ & $\begin{array}{l}\text { No simple } \\
\text { proficiency } \\
\text { effect for MF }\end{array}$ & $\begin{array}{l}\text { PI ratings } \\
\text { increase with } \\
\text { proficiency in } \\
\text { Certainty } \\
\text { contexts }\end{array}$ \\
\hline
\end{tabular}

Note: N/A denotes not applicable.

\section{Discussion}

The purpose of this study was to examine the acquisition of variable future-time expression in two groups of multicompetent speakers (HLLs and L2 learners). While the HLLs were exposed to NS input from an early age, L2 learners were exposed to textbooks and classroom input where little attention is devoted to the variables that regulate the distribution of the different expressions of futurity. Thus, HLLs and L2 learners in this study differed in their Spanish input. Through an AJT, we addressed three RQs. Our first $\mathrm{RQ}$ (How do participants rate the three variants of future-time expression (PF, MF, and PI)?) gave us a point of departure to understand the distribution of these three forms in the ratings of HLLs and L2 learners. Overall, both groups showed a preference for the PF and the MF (with average ratings approximately between 3 and 3.5) over the PI (with average ratings approximately between 2 and 2.5). The high ratings of the MF might be surprising when we compared them with the rates of usage reported in the literature. For instance, Orozco and Thoms (2014) provided the average frequencies of these three verb forms by collating data from 12 studies that explored future-time expression in Latin America, Spain, and the US. The reported frequencies were $11.4 \%$ for the MF, $17.8 \%$ for the PI, and $70.8 \%$ for the PF. Here we see a clear pattern in which PF is the default form while the PI and, particularly, the MF have a much lower frequency of use. Although our study did not report percentage of use, based on the frequencies reported in the above-mentioned study, we might expect the PF to have much higher ratings than the other two forms. Instead, the PF and the MF had very similar ratings. It is important to point out the difference between use reported in production tasks and acceptability of forms in an AJT. The MF is an acceptable form. Therefore, we attributed these findings to the nature of the task and the fact that our participants were instructed learners in Spanish-language classrooms. The MF was shown to be used mostly in formal contexts, such as the written register (Sedano 2006), and is present in Spanish-language textbooks, to which both groups of participants were exposed. The lower rating of the PI can be attributed to its primary use to refer to the present time. Lastly, the metalinguistic nature of the task may have elicited metalinguistic knowledge, particularly in the case of the L2 learners, since they certainly received grammar instruction on this topic. Textbooks present the MF as the default future-time expression in Spanish (Orozco and Thoms 2014). 
To address our second RQ (What linguistic factors constrain the ratings of each variant (PF, MF, and PI) in HLLs and L2ers?), we focused on the interactions between verb form and each of the other fixed effects.

The effect of certainty in previous research indicated that the MF is a marker of uncertainty (Blas Arroyo 2008) and the PF is a marker of either certainty (Gudmestad and Geeslin 2011, NS group) or neither certainty nor uncertainty (Claes and Ortiz López 2011) in Spanish NSs. L2 learners in Gudmestad and Geeslin (2011) were not sensitive to this variable. In their study on the progression of acquisition of future-time expression, Gudmestad and Geeslin (2013) showed that the identification of the MF and PI with certainty occurred from early stages of acquisition, especially for the PI. Certainty was significant in our data for the HLLs, while it was modulated by proficiency in the L2 learners (i.e., significance depended on proficiency score). As proficiency increased, the MF was rated higher in contexts of certainty than doubt in the L2 group, departing from NS usage but in line with the results reported in Gudmestad and Geeslin (2013). Overall, the HLLs were similar in the direction of effect of this variable to monolingual NSs, while L2 learners were sensitive to the variable but departed from monolingual NS norms in the direction of the effect for the MF.

With respect to temporal distance, previous research seemed to converge on the PF as the form that is not marked for temporal distance, the PI as the close future form, and the MF as the distant future form (Blas Arroyo 2008; Claes and Ortiz López 2011; Díaz-Campos and Escalona Torres 2018; Gudmestad and Geeslin 2011; Kanwit 2021; Kanwit and Solon 2013). For both groups in the current study, the results regarding the PF and PI were similar and reflected the trend previously attested in the literature. The MF was not associated with any temporal distance in the HLLs, while it was associated with a more distant future among the L2 learners with a higher proficiency, a result consistent with the previous L2 literature. The results from the HLLs may be attributed to the low use of the MF in Latin America and the US (7.2\% in NYC Colombians in Orozco 2007). The lower frequency of the MF in the HLL input may indicate that, whereas they were familiar with the form, they did not currently associate it with temporal distance.

The effect of presence of a temporal adverb was also previously examined, as it can help guide the use of forms that may not mark future in their morphology, as was the case of the PI. Specifically, previous research indicated that the use of the PI was associated with the presence of an adverb, while the use of the MF and PF was not (Blas Arroyo 2008; Gudmestad and Geeslin 2011; Kanwit and Solon 2013). Our results were consistent with previous research. Both groups rated sentences in the PI higher with an adverb than without it. While the presence of the adverb did not impact the ratings of the MF, it did for the PF, which received higher ratings when there was no adverb present. This result seemed to indicate that the PF was the default future marker. The MF, as was the case with other variables, did not seem to have such a clear pattern in these speakers.

All in all, these data indicate different patterns for the three verb forms, where the PF functioned as the default form, and the MF and PI had dedicated spaces of acceptability. These trends were clearer in the case of the HLLs, while, in the case of L2 learners, it was modulated by proficiency (as was the case for certainty and temporal distance). As the default marker of futurity, the PF was not associated with a particular temporal distance and was rated higher without an adverb. The PF signaled certainty. The PI was associated with certainty and proximity and was more acceptable with a temporal adverb that signified futurity. The MF was associated with uncertainty (for HLLs) and temporal distant events (for L2 learners), whereas the presence of the adverb did not have an impact on ratings. Thus, consistent with previous literature, our data reflected systematic variation of these variants in these two groups of speakers.

Our third RQ focused on the role that proficiency and speaker group (HLL vs. L2 learner) could play in the expression of futurity. Our analyses confirmed some differences between the groups, which we attributed to the source of their input (other NSs in their community, in the case of HLLs, and textbook and classroom Spanish in the case 
of L2 learners). For example, certainty had a significant effect on verb form in the HLL group, while, for the L2 learners, certainty was modulated by proficiency. Since HLLs were exposed to NS Spanish where certainty was widely attested to have an effect, it was not surprising that their ratings indicated an effect of the variable certainty. In the case of L2 learners, the rating of the MF was higher in contexts of certainty than doubt only at higher proficiency levels, which did not parallel the trend attested in the HLLs or NSs in previous research. Since the MF is presented as the default for future-time expression and certainty is not part of the explanation in textbooks (Orozco and Thoms 2014) ${ }^{4}$, the results for L2 learners in this study were not surprising. Also related to the context of acquisition was the difference in the association of the MF with a distant future. It is possible that the lower use of the MF in a natural setting resulted in the HLLs not having enough evidence to make this association. For L2 learners, there was an effect for temporal distance, but it was modulated by proficiency. L2 learners are initially exposed to the PF, and the MF is then introduced as the default marker of futurity. One of the textbooks explored, for instance, mentioned the PF is used for actions in the very near future, while the MF is used for actions in the near or distant future. Thus, with time, L2 learners were introduced to several forms for expressing futurity, and temporal distance was likely to be part of the explanation provided.

The second difference between speaker groups was the effect of proficiency, which modulated the acquisition of the effect of temporal distance on verb form and the effect of certainty on verb form in L2 learners. At higher levels of proficiency, ratings for the MF increased with distant events and contexts of certainty. We partially ascribed the L2 results to the possible effect of instruction. Even though the PF was introduced first, the MF was introduced as the paramount expression of futurity. Only three of the 13 intermediate-level books reviewed in Orozco and Thoms (2014) formally presented forms other than the MF. Explanations in textbooks normally only included reference to the PI being used for a near future. This instruction may make it more difficult to make the necessary associations, specifically between the three variants and certainty. Thus, L2 learners have to learn that the MF is not the default form and have to restrict its acceptability, which our data showed happening with proficiency for temporal distance but not for certainty, in that with proficiency they associated the MF with certainty, instead of with uncertainty, as in the NS norm and the HLLs.

Overall, the present paper indicated acquisition of the systematic variation associated with the three verb forms examined here in both groups, to different degrees. The results for the HLLs were difficult to compare to some of the previous studies on heritage Spanish, given the different focus of previous research (e.g., the different functions of the MF in Gutiérrez 1995) and/or the fact that the fixed effects we examined were not included in the analysis (Gutiérrez 1995). However, in line with Orozco $(2007,2015)$, we can conclude that there was evidence of sensitivity to the constraints identified in the monolingual Spanish literature, with the direction of effect previously established. The only difference present was in the lack of a relationship between the MF and a distant event. This difference may be due to the limited presence of the MF in their input or to the grammatical explanation in textbooks, where the MF was presented as the default in terms of temporal distance.

Nonetheless, unlike other aspects of Spanish morphosyntax where incomplete acquisition (Montrul 2008) or convergent simplification (Silva-Corvalán 1994) was reported in studies on heritage Spanish, our data on future-time expression mostly showed systematic variation comparable to that reported for monolingual NSs in previous literature. Moreover, for the L2 learners, similar to previous literature, there was (i) an attenuated effect of certainty, modulated by proficiency and tending toward a non-targetlike pattern (Gudmestad and Geeslin 2011, 2013), (ii) an effect for the presence of a temporal adverb (Gudmestad and Geeslin 2011; Kanwit and Solon 2013), and (iii) an effect of temporal distance (Gudmestad and Geeslin 2011; Kanwit 2021; Kanwit and Solon 2013). Our data, thus, indicated that the HLLs had an advantage, as compared to the L2 learners, in the acquisition of future-time expression. We attributed this advantage to the different linguistic experiences of the two 
participant groups, although other factors may also be at play (e.g., the age of onset of bilingualism). The HLLs had access to input where certainty, temporal distance, and the presence of a temporal adverb had an effect on the distribution of these variants, while the L2 learners were exposed to grammatical explanations in textbooks where the linguistic constraints were largely omitted.

Finally, this study had two main limitations. First, the (written) nature of the AJT task may lend itself to conscious use of metalinguistic knowledge by participants and did not allow us to make observations about usage. To counteract this effect, we collected oral data from the same speakers through a sociolinguistic interview that will allow us, in future research, to assess the effect of different methods of data collection on our findings. Additionally, we controlled for several variables (e.g., clause type, person, negation, and verb type), and thus it remains to be ascertained how these factors may impact the expression of futurity in Spanish, and we invite future research to examine these factors in the acquisition of Spanish by multicompetent speakers. Nevertheless, given the similarities with results from previous studies, we remain confident that the methodology allowed us to compare HLLs' and L2 learners' variable patterns of acceptability of future-time verb forms.

\section{Conclusions}

The present paper aimed to uncover the acceptability ratings of three verb forms ( $\mathrm{PF}$, $\mathrm{MF}$, and PI) used to express futurity in Spanish, depending on three linguistic factors that constrain their distribution: certainty, temporal distance, and the presence of an adverb, in two groups of multicompetent speakers whose dominant language is English through a contextualized AJT. Our findings revealed that the HLLs mostly aligned with the results in previous literature. However, given the nature of the AJT, they assigned high ratings to the MF. This could be a byproduct of the written nature of the task, and, very likely, due to differences in production versus acceptance of variable forms. Importantly, our data did not offer clear evidence of an effect of the textbook explanations for these speakers, other than possibly the lack of temporal distant association with the MF, even though they were instructed HLLs. L2 learners showed a trend in which, as proficiency increased, the significance and direction of effects of the linguistic factors started to surface and paralleled those of monolingual NSs (for some factors). This could indicate that they were in fact becoming more sensitive to other sources of input and restructuring their grammar and certain aspects of what they were taught in the classroom to converge on a distribution of the forms that resemble the distribution of forms in monolingual and bilingual NS grammars. The difficulty in the acquisition of future-time expression due to the lack of specificity in grammatical explanations in textbooks could only be remedied if textbook publishers and linguists collaborated to guarantee that their explanations and activities, as well as the input provided to students through reading and listening, truly reflect NS patterns of use (Orozco and Thoms 2014). Overall, our data was consistent with an HLL advantage over L2 learners in the acquisition of the future-time expression, which we attributed mostly to input exposure. Thus, the input seemed to offer enough evidence of these linguistic constraints for the HLLs to be able to acquire future-time expression in Spanish.

Author Contributions: Conceptualization, A.d.P.P. and I.G.S.; Data curation, A.d.P.P. and I.G.S.; Formal analysis, A.d.P.P. and N.F.; Methodology, A.d.P.P. and I.G.S.; Resources, A.d.P.P. and I.G.S.; Writing-original draft preparation, A.d.P.P., I.G.S. and N.F.; writing—review and editing, A.d.P.P., I.G.S. and N.F. All authors have read and agreed to the published version of the manuscript.

Funding: This research was funded by National Institute on Deafness and Other Communication Disorders, grant number T32-DC000052.

Institutional Review Board Statement: The study was conducted according to the guidelines of the Declaration of Helsinki, and approved by the Institutional Review Board of the University of Florida (protocol code 2015-U-0153 approved on 18 May 2017). 
Informed Consent Statement: Informed consent was obtained from all subjects involved in the study.

Data Availability Statement: The data presented in this study are available on request from the corresponding author. The data are not publicly available due to ethical reasons.

Conflicts of Interest: The authors declare no conflict of interest.

\section{Appendix A. Instrument: Contextualized Acceptability Judgment Task}

\section{CONDITION A: Doubt, close, no adverb [-certain] [+close] [-adverb]}

1. Javier le pregunta a su hijo qué tiene que hacer por la tarde después del colegio. El chico, aunque todavía no lo sabe con seguridad, contesta:
a. Voy a jugar al fútbol
b. Jugaré al fútbol
c. Juego al fútbol

2. Rosa le pregunta a su hermana si va a cenar en casa esa noche. Aunque no tiene planes definitivos, ella contesta:
a. Voy a cenar con mis amigas
b. Cenaré con mis amigas
c. Ceno con mis amigas

3. Diego le pregunta a su mujer qué planes tiene para mañana. Ella, no está muy segura todavía, pero contesta:
a. Voy a llevar a los chicos al médico
b. Llevaré a los chicos al médico
c. Llevo a los chicos al médico

4. Pablo le pregunta a Ana qué piensa hacer mañana. Aunque no está muy segura, ella le contesta.
a. Voy a estudiar
b. Estudiaré
c. Estudio

5. Carlos le pregunta a su compañero de trabajo qué va a hacer este fin de semana. Aunque él no está totalmente seguro, contesta:
a. Voy a visitar a mi familia
b. Visitaré a mi familia
c. Visito a mi familia

6. Carmen le pregunta a su hija si tiene planes para el fin de semana. Su hija, aunque no lo ha decidido todavía completamente, contesta:
a. Voy a ir al cine
b. Iré al cine
c. Voy al cine

\section{CONDITION B: Doubt, close, adverb [-certain] [+close] [+adverb]}

1. Alicia lleva enferma una semana. Su madre le pregunta si tiene pensado ir al médico. Ella no está segura pronto pero contesta.
a. Esta tarde voy a ir al médico
b. Esta tarde iré al médico
c. Esta tarde voy al médico

2. María le pregunta a su hijo por sus planes para esta tarde. Aunque no está seguro del todo, contesta:
a. Esta tarde voy a jugar al baloncesto
b. Esta tarde jugaré al baloncesto
c. Esta tarde juego al baloncesto 
3. Julio no ha estudiado mucho para el examen de mañana y, aunque no está muy seguro, le dice a su compañero de clase:
a. Mañana voy a aprobar el examen
b. Mañana aprobaré el examen
c. Mañana apruebo el examen

4. Clara está pensando en empezar una nueva dieta. No está muy convencida de poder hacerlo así que se dice a sí misma:
a. Mañana voy a comer más verduras
b. Mañana comeré más verduras
c. Mañana como más verduras

5. Belén le pregunta a su hermana sus planes para el fin de semana. Aunque no lo sabe con plena seguridad, contesta:
a. Este fin de semana voy a salir con mis amigos
b. Este fin de semana saldré con mis amigos
c. Este fin de semana salgo con mis amigos

6. Pedro le pregunta a su padre por sus planes para el fin de semana. Él, aunque no lo ha decidido totalmente, contesta:
a. Este fin de semana voy ir a la playa
b. Este fin de semana iré a la playa
c. Este fin de semana voy a la playa

\section{CONDITION C: Doubt, distant, no adverb [-certain] [-close] [-adverb]}

1. El consejero académico le pregunta a Sara qué clases está pensando tomar el próximo año. Ella, aunque no está completamente segura, contesta:
a. Voy a tomar Literatura Española
b. Tomaré Literatura Española
c. Tomo Literatura Española

2. Pablo le pregunta a su compañero si piensa quedarse en la misma empresa el año que viene. Él no lo ha decidido completamente, sin embargo, le dice:
a. Voy a cambiar de trabajo
b. Cambiaré de trabajo
c. Cambio de trabajo

3. En una entrevista de trabajo para un puesto de psiquiatra, el entrevistador pregunta a Rosa dónde se ve ella en los próximos 5 años. No está segura pero contesta.
a. Voy a tener mi propia clínica
b. Tendré mi propia clínica
c. Tengo mi propia clínica

4. Belén le pregunta a Mercedes por su relación con David y si piensan casarse en los próximos 5 años. Aunque ella no está segura, contesta:
a. Voy a mudarme a Nueva York con David
b. Me mudaré a Nueva York con David
c. Me mudo a Nueva York con David

5. El médico le pregunta a Clara cuántos hijos planea tener en los próximos 10 años. No lo ha decidido aún así que responde:
a. Voy a tener dos hijos.
b. Tendré dos hijos
c. Tengo dos hijos

6. En el banco, el asesor le pregunta a Paula por sus planes de futuro y si piensa hacer una gran compra en los próximos 10 años. Ella, aunque no está segura si tendrá el dinero suficiente, contesta: 

a. Voy a comprar una casa en la playa
b. Compraré una casa en la playa
c. Compro una casa en la playa

\section{CONDITION D: Doubt, distant, adverb [-certain] [-close] [+adverb]}

1. María le pregunta a su compañera de cuarto si quiere seguir viviendo en el campus o en otro lugar. Ella no lo ha decidido todavía. Sin embargo, le contesta:
a. El año que viene voy a cambiarme de casa
b. El año que viene me cambiaré de casa
c. $\quad$ El año que viene me voy a cambia de casa

2. Tere le pregunta a Cristina si tiene pensado empezar algún hobby nuevo el próximo año. Ella no lo tiene completamente decidido pero contesta:
a. El año que viene voy a tomar clases de flamenco
b. El año que viene tomaré clases de flamenco
c. El año que viene voy a tomar clases de flamenco

3. Vero le pregunta a Julio dónde piensa trabajar en 5 años. Aunque él realmente no lo sabe, responde:
a. $\quad$ En 5 años voy a trabajar en España
b. En 5 años trabajaré en España
c. En 5 años trabajo en España

4. A Juan le gusta escribir en su tiempo libre. Su amiga le pregunta qué piensa publicar en los próximos 5 años. Aunque no está seguro de poder hacerlo, él contesta:
a. $\quad$ En 5 años voy a publicar una novela corta
b. En 5 años publicaré una novela corta
c. En 5 años publico una novela corta

5. En una entrevista, el entrevistador le pregunta a Pablo cuáles son sus objetivos profesionales para los próximos 10 años. Él, sin total certeza, contesta:
a. En 10 años voy a montar mi propia empresa
b. En 10 años montaré mi propia empresa
c. En 10 años voy a montar mi propia empresa

6. Carolina le pregunta a su abuela qué piensa hacer en los próximos 10 años. Ella, aunque no lo sabe con seguridad, le contesta:
a. En 10 años voy a mudarme a Florida
b. En 10 años me mudaré a Florida
c. En 10 años me mudo a Florida

\section{CONDITION E: No doubt, close, no adverb [+certain] [+close] [-adverb]}

1. La profesora le pregunta a Fernando qué planes tiene para esta tarde. Él contesta sin dudar:
a. Voy a tomar una clase de piano
b. Tomaré una clase de piano
c. Tomo clase de piano

2. Paula le pregunta a su marido qué planes tiene para esta tarde. Como es jueves, él sabe con seguridad lo que va a hacer y le contesta:
a. Voy a ir a jugar al fútbol
b. Jugaré al fútbol
c. Voy a jugar al fútbol

3. Juan quiere saber qué piensa hacer María mañana. Ella le contesta con total seguridad:
a. Voy a ir de compras
b. Iré de compras
c. Voy de compras 
4. María le pregunta a Cristina qué va a hacer mañana. A Cristina le duele la espalda desde hace días así que lo tiene decidido. Le contesta:
a. Voy a nadar en la piscina
b. Nadaré en la piscina
c. Nado en la piscina

5. Juan ha planeado su fin de semana a la perfección. Le cuenta a Pedro sus planes para el fin de semana:
a. Voy a viajar a Chicago
b. Viajaré a Chicago
c. Voy a viajar a Chicago

6. Ángel le pregunta a Inés si quiere cenar con ella el fin de semana. Ella sabe que no puede así que le contesta.
a. Voy a cenar con mis padres
b. Cenaré con mis padres
c. Ceno con mis padres

\section{CONDITION F: No doubt, close, adverb [+certain] [+close] [+adverb]}

1. María quiere que su novio sepa que no puede salir con él esta tarde. Ella le dice muy convencida:
a. Esta tarde voy a correr una maratón
b. Esta tarde correré una maratón
c. Esta tarde corro una maratón

2. Su amigo le pregunta a Juan qué piensa hacer esta tarde. Él, que ya ha quedado con su entrenador personal, le dice:
a. Esta tarde voy a hacer ejercicio
b. Esta tarde haré ejercicio
c. Esta tarde hago ejercicio

3. Laura le pregunta a Beatriz qué piensa hacer mañana. Beatriz, que lo tiene todo calculado, responde:
a. Mañana voy a ir al teatro
b. Mañana iré al teatro mañana
c. Mañana voy al teatro

4. Rafa le pregunta a su novia por sus planes para mañana. Ella contesta con total seguridad:
a. Mañana voy a quedar con mis amigas
b. Mañana quedaré con mis amigas
c. Mañana quedo con mis amigas

5. Laura le pregunta a su amiga qué actividad pueden hacer este fin de semana juntas. Ella ya lo tienen planeado así que le dice:
a. Este fin de semana voy a hacer yoga
b. Este fin de semana haré yoga
c. Este fin de semana hago yoga

6. María y Raquel hablan sobre los planes del fin de semana. Raquel ya ha comprado las entradas así que le dice:
a. Este fin de semana voy a ir un concierto
b. Este fin de semana iré a un concierto
c. Este fin de semana voy a un concierto

\section{CONDITION G: No doubt, distant, no adverb [+certain] [-close] [-adverb]}

1. Ángela y su mejor amiga hablan de las cosas nuevas que quieren hacer el próximo año. Ella lo tiene claro y le dice: 

a. Voy a aprender japonés
b. Aprenderé japonés
c. Aprendo japonés

2. Rosa le cuenta a su amiga los problemas que está teniendo con las clases de su carrera. Lo tiene decidido así que le dice con total certeza:
a. Voy a cambiar de carrera
b. Cambiaré de carrera
c. Cambio de carrera

3. Cristina le pregunta a su madre qué planes tiene para los próximos 5 años. Como ella nunca pudo terminar sus estudios, lo tiene completamente decido, y le contesta:
a. Voy a volver a la universidad
b. Volveré a la universidad
c. Vuelvo a la universidad

4. Sus padres le preguntan a Julia cuáles son sus objetivos para los próximos 5 años. Ella, que ya ha pensado en esto, contesta sin dudar:
a. Voy a comprar una casa
b. Compraré una casa
c. Compro una casa

5. La profesora de Luis le pregunta dónde se ve en los próximos 10 años. Él contesta sin dudar:
a. Voy a hacer un doctorado
b. Haré un doctorado
c. Hago mi doctorado

6. La profesora de Biología le pregunta a Martín dónde se ve en los próximos 10 años. Martín lo tiene claro y responde:
a. Voy a trabajar en un hospital
b. Trabajaré en un hospital
c. Trabajo en un hospital

\section{CONDITION H: No doubt, distant, adverb [+certain] [-close] [+adverb]}

1. Jennifer y Carlos hablan sobre sus clases para el próximo año. Jennifer ya ha decidido que va a tomar y dice:
a. $\quad$ El año que viene voy a tomar Biología
b. El año que viene tomaré Biología
c. El año que viene tomo Biología

2. Lorena le cuenta a su amiga todos los problemas que tiene en su casa. Lo tiene completamente decidido así que le dice:
a. El año que viene voy a cambiar de casa
b. El año que viene cambaré de casa
c. El año que viene cambio de casa

3. Marina nunca ha tenido mascotas porque está muy ocupada con su trabajo. En 5 años tendrá más tiempo libre así que lo ha decidido. Se dice a sí misma:
a. $\quad$ En 5 años voy a comprar un perro
b. En 5 años me comparé un perro
c. En 5 años compro un perro

4. Juan es residente de medicina. En 5 años termina su residencia y estará mucho más relajado. Le dice a su amigo totalmente convencido:
a. $\quad$ En 5 años voy a tomarme los fines de semana libres
b. $\quad$ En 5 años me tomaré los fines de semana libres
c. En 5 años me tomo los fines de semana libres 
5. Sus hijos le preguntan a José qué piensa hacer en 10 años cuando se jubile. Él, con total certeza, les dice:
a. $\quad$ En 10 años voy a hacer un viaje alrededor del mundo
b. $\quad$ En 10 años haré un viaje alrededor del mundo
c. $\quad$ En 10 años hago un viaje alrededor del mundo

6. El jefe de Juan quiere saber cuándo piensa dejar de trabajar para la empresa. Él, completamente seguro, le contesta:
a. En 10 años me voy a jubilar
b. En 10 años me jubilaré
c. En 10 años me jubilo

\section{Appendix B. Final Equation for Both Groups of Speakers}

clmm(RATING $\sim 1+$ VerbForm + Proficiency + Certainty + Proficiency:Certainty + VerbForm:Proficiency + VerbForm:Certainty + Distance + VerbForm:Distance + Certainty:Distance + Adverb + VerbForm:Adverb + Distance:Adverb + SpeakerType + VerbForm:SpeakerType + Certainty:SpeakerType + VerbForm:Certainty:SpeakerType + Adverb:SpeakerType + VerbForm:Adverb:SpeakerType + Distance:SpeakerType + Certainty: Distance:SpeakerType + Distance:Adverb:SpeakerType + Proficiency:SpeakerType + VerbForm:Proficiency:SpeakerType + Proficiency:Distance + VerbForm:Distance:Proficiency + (1 I Participant $)+(1$ Item $)$, data=both_groups, link="probit")

\section{Appendix C. Final Equation for the HLLs}

$\operatorname{clmm}($ RATING $\sim 1+$ VerbForm + Proficiency + Certainty + VerbForm:Certainty + Proficiency:Certainty + VerbForm:Proficiency + Distance + VerbForm:Distance + Certainty:Distance + Adverb + VerbForm:Adverb + Distance:Adverb + (1 I Participant) +(1 I Item), data=heritage, link="probit")

\section{Appendix D}

Final model of HLL AJT ratings, with proficiency (reference level is PF, No doubt, Distant future, Adverb present, proficiency centered at average)

NB: The parameter estimate indicates the direction of the effect with respect to the reference category. The reference level was PF, No doubt, Distant future, Adverb present, proficiency centered at average. For Verb Form, for example, the HLLs were less likely to rate the PI or the MF as high as the PF, as per the negative parameter estimate, although caution is advised with this interpretation, since there are interactions involving Verb Form.

\begin{tabular}{lcccc}
\hline Fixed Effects \& Interactions & $\beta$ & $S E$ & $z$ & $p$ \\
\hline VerbForm (PI) & -1.495 & 0.072 & -20.641 & $<0.001$ \\
VerbForm (MF) & -0.275 & 0.075 & -3.651 & $<0.001$ \\
Proficiency & 0.033 & 0.009 & 3.737 & $<0.001$ \\
Certainty (Doubt) & -0.577 & 0.070 & -8.267 & $<0.001$ \\
Distance (Close) & -0.297 & 0.080 & -3.723 & $<0.001$ \\
Adverb (No Adverb) & 0.080 & 0.069 & 1.156 & 0.248 \\
VerbForm x Certainty (PI, Doubt) & 0.175 & 0.070 & 2.483 & 0.013 \\
VerbForm x Certainty (MF, Doubt) & 0.592 & 0.075 & 7.938 & $<0.001$ \\
Proficiency x Certainty (Doubt) & -0.021 & 0.004 & -5.821 & $<0.001$ \\
Proficiency x VerbForm (PI) & -0.018 & 0.004 & -4.204 & $<0.001$ \\
Proficiency x VerbForm (MF) & -0.003 & 0.005 & -0.670 & 0.503 \\
VerbForm x Distance (PI, Close) & 0.386 & 0.070 & 5.495 & $<0.001$ \\
VerbForm x Distance (MF, Close) & 0.020 & 0.074 & 0.269 & 0.788 \\
Certainty x Distance (Doubt, Close) & 0.242 & 0.076 & 3.203 & 0.001 \\
VerbForm x Adverb (PI, No adverb) & -0.518 & 0.070 & -7.372 & $<0.001$ \\
VerbForm x Adverb (MF, No adverb) & -0.063 & 0.074 & -0.843 & 0.399 \\
Distance x Adverb (Close, No adverb) & 0.178 & 0.075 & 2.359 & 0.018 \\
\hline
\end{tabular}




\begin{tabular}{lcc}
\hline & Random Effects & \\
\hline & Variance & S.D. \\
Item & 0.007 & 0.085 \\
Participant & 0.204 & 0.451 \\
\hline
\end{tabular}

Model fit (LL): -6679.61.

\section{Appendix E Final Equation for the L2 Learners}

clmm(RATING $\sim 1+$ VerbForm + Proficiency + VerbForm:Proficiency + Certainty + Proficiency:Certainty + Distance + VerbForm:Distance + Proficiency:Distance + VerbForm:Proficiency:Distance + VerbForm:Certainty + VerbForm:Proficiency:Certainty + Adverb + VerbForm:Adverb + (1 I Participant $)+(1$ I Item), data=L2, link="probit")

\section{Appendix F}

Final model of L2 learner AJT ratings, with proficiency (reference level is PF, No doubt, Distant future, Adverb present, proficiency centered at average)

\begin{tabular}{lllll}
\hline Fixed Effects \& Interactions & $\beta$ & $S E$ & $z$ & $p$ \\
\hline VerbForm (PI) & -1.361 & 0.074 & -18.418 & $<0.001$ \\
VerbForm (MF) & 0.078 & 0.077 & 1.012 & 0.312 \\
Proficiency & 0.032 & 0.012 & 2.687 & 0.007 \\
Certainty (Doubt) & -0.046 & 0.057 & -0.807 & 0.420 \\
Distance (Close) & 0.047 & 0.057 & 0.828 & 0.408 \\
Adverb (No Adverb) & 0.120 & 0.056 & 2.125 & 0.034 \\
Proficiency x VerbForm (PI) & -0.014 & 0.008 & -1.787 & 0.074 \\
Proficiency x VerbForm (MF) & -0.014 & 0.008 & -1.737 & 0.082 \\
Proficiency x Certainty (Doubt) & -0.002 & 0.007 & -0.325 & 0.746 \\
VerbForm x Distance (PI, Close) & 0.248 & 0.073 & 3.394 & $<0.001$ \\
VerbForm x Distance (MF, Close) & -0.167 & 0.077 & -2.171 & 0.030 \\
Proficiency x Distance (Close) & 0.001 & 0.007 & 0.214 & 0.831 \\
VerbForm x Certainty (PI, Doubt) & -0.085 & 0.073 & -1.162 & 0.245 \\
VerbForm x Certainty (MF, Doubt) & -0.071 & 0.077 & -0.928 & 0.354 \\
VerbForm x Adverb (PI, No adverb) & -0.241 & 0.073 & -3.306 & $<0.001$ \\
VerbForm x Adverb (MF, No adverb) & -0.068 & 0.077 & -0.891 & 0.373 \\
VerbForm x Proficiency x Distance (PI, Close) & 0.015 & 0.009 & 1.692 & 0.091 \\
VerbForm x Proficiency x Distance (MF, Close) & -0.015 & 0.009 & -1.601 & 0.109 \\
VerbForm x Proficiency x Certainty (PI, Doubt) & -0.026 & 0.009 & -2.986 & 0.003 \\
VerbForm x Proficiency x Certainty (MF, Doubt) & -0.013 & 0.009 & -1.401 & 0.161 \\
\hline Random Effects & & & & \\
\hline & Variance & & S.D. & \\
Item & 0.002 & & 0.046 & \\
Participant & 0.312 & & 0.559 & \\
\hline Model fit (LL) - 6135.03. & & & \\
\hline
\end{tabular}

Model fit (LL): -6135.03.

\section{Notes}

1 We use the label HS to refer to any type of bilingual that conforms with Valdés' (2000) definition. We use the label HLLs to refer specifically to instructed HSs, such as our participants, who were attending university Spanish classes at the time of the study.

2 It is important to clarify here that some of the NSs in L2 studies were not monolingual but future-time expression seemed to be constrained by similar factors as monolinguals.

3 We included all the variables and interactions and used the buildmer package to select the model. Given the inclusion of several variables from previous research, we chose a maximal fixed effects approach initially to explore how these different variables best predict speaker development of future-time expression. We acknowledge this is a relatively less conservative approach. Nonetheless, we focus our discussion on interactions involving the variable verb form as they are central to our research questions.

4 Orozco and Thoms (2014) do not report on the explanation of uses per se. We examined the two textbooks used in the institutions where the data were collected and no reference to certainty was included. 


\section{References}

Au, Terry Kit-Fong, Leah M. Knightly, Sun-Ah Jun, and Janet S. Oh. 2002. Overhearing a Language during Childhood. Psychological Science 13: 238-43. [CrossRef] [PubMed]

$\mathrm{Au}$, Terry Kit-Fong, Janet S. Oh, Leah M. Knightly, Sun-Ah Jun, and Laura F. Romo. 2008. Salvaging a Childhood Language. Journal of Memory and Language 58: 998-1011. [CrossRef] [PubMed]

Blas Arroyo, José Luis. 2008. The Variable Expression of Future Tense in Peninsular Spanish: The Present (And Future) of Inflectional Forms in the Spanish Spoken in a Bilingual Region. Language Variation and Change 20: 85-126. [CrossRef]

Carvalho, Ana M., Rafael Orozco, and Naomi Lapidus Shin, eds. 2015. Subject Pronoun Expression in Spanish: A Cross-Dialectal Perspective. Washington, DC: Georgetown University Press.

Christensen, Rune Haubo Bojesen. 2019. Ordinal—Regression Models for Ordinal Data. R Package Version December 10, 2019. Available online: https:/ /CRAN.R-project.org/package=ordinal (accessed on 1 May 2021).

Claes, Jeroen, and Luis A. Ortiz López. 2011. Restricciones Pragmáticas y Sociales en la Expresión de Futuridad en el Español de Puerto Rico. Spanish in Context 8: 50-72. [CrossRef]

Cuza, Alejandro, and Joshua Frank. 2015. On the Role of Experience and Age-related effects: Evidence from the Spanish CP. Second Language Research 31: 3-28. [CrossRef]

Díaz-Campos, Manuel, and J. Escalona Torres. 2018. Corpus approaches to the study of language, variation and change. In Cambridge Handbook of Spanish Linguistics. Edited by Kimberly Geeslin. Cambridge: CUP, pp. 121-41.

Díaz-Peralta, Marina, and J. Manuel Almeida. 2000. Sociolinguistic Factors in Grammatical Change: The Expression of the Future in Canarian Spanish. Studia Neophilogica 72: 217-28. [CrossRef]

Geeslin, Kimberly L., and Avizia Yim Long. 2014. Sociolinguistics and Second Language Acquisition: Learning to Use Language in Context. New York: Routledge.

Giancaspro, David, and Liliana Sánchez. 2021. Me, Mi, My: Innovation and Variability in Heritage Speakers' Knowledge of Inalienable Possession. Glossa: A Journal of General Linguistics 6: 1-28. [CrossRef]

Gudmestad, Aarnes. 2021. Variationist approaches. In The Routledge Handbook of Second Language Acquisition and Corpora. Edited by Nicole Tracy-Ventura and Magali Paquot. New York: Routledge, pp. 230-41.

Gudmestad, Aarnes, and Kimberly L. Geeslin. 2011. Assessing the Use of Multiple Forms in Variable Contexts: The relationship between Linguistic Factors and Future-time Reference in Spanish. Studies in Hispanic and Lusophone Linguistics 4: 3-34. [CrossRef]

Gudmestad, Aarnes, and Kimberly L. Geeslin. 2013. Second-language Development of Variable Forms of Future-time Expression in Spanish. In Selected Proceedings of the 6th Workshop on Spanish Sociolinguistics. Edited by Sara Beaudrie and Ana M. Carvalho. Somerville: Cascadilla Proceedings Project, pp. 63-75.

Gutiérrez, Manuel J. 1995. On the Future of the Future Tense in the Spanish of the Southwest. In Spanish in Four Continents: Studies in Language Contact and Bilingualism. Edited by Carmen Silva-Corvalán. Washington, DC: Georgetown University Press, pp. 214-23.

Kanwit, Matthew. 2013. L1 Child Acquisition of Future Expression in Madrileño Spanish: A Variationist Study. In Selected Proceedings of the 16th Hispanic Linguistics Symposium. Edited by Jennifer Cabrelli Amaro, Gillian Lord, Ana de Prada Pérez and Jessi Elana Aaron. Somerville: Cascadilla Proceedings Project, pp. 222-37.

Kanwit, Matthew. 2021. Allowable Temporal Distances for Future-time Forms. In Advancedness in Second Language Spanish: Definitions, Challenges, and Possibilities. Edited by Mandy Menkke and Paul Malovrh. Amsterdam: John Benjamins, pp. 115-42.

Kanwit, Matthew, and Megan Solon. 2013. Acquiring Variation in Future-time Expression Abroad in Valencia, Spain and Mérida, Mexico. In Selected Proceedings of the 16th Hispanic Linguistics Symposium. Edited by Jennifer Cabrelli Amaro. Somerville: Cascadilla Proceedings Project, pp. 206-21.

Knightly, Leah M., Sun-Ah Jun, Janet S. Oh, and Terry Kit-Fong Au. 2003. Production Benefits of Childhood Overhearing. Journal of the Acoustic Society of America 114: 465-74. [CrossRef]

Lastra, Yolanda, and Pedro M. Butragueño. 2010. Futuro Perifrástico y Futuro Morfológico en el Corpus Sociolingüístico de la Ciudad de México. Oralia 13: 145-71.

Lenth, Russell. 2020. Emmeans: Estimated Marginal Means, aka Least-Squares Means. R Package Version 1.4.8. Available online: https:/ /CRAN.R-project.org/package=emmeans (accessed on 1 May 2021).

Montrul, Silvina. 2008. Incomplete Acquisition in Bilingualism: Re-examining the Age Factor. Amsterdam: John Benjamins.

Montrul, Silvina. 2011. Multiple Interfaces and Incomplete Acquisition. Lingua 121: 591-604. [CrossRef]

Montrul, Silvina. 2016. The Acquisition of Heritage Languages. Cambridge: Cambridge University Press.

Montrul, Silvina, and Roumyana Slabakova. 2003. Competence Similarities between Native and Near-native Speakers: An investigation of the Preterite/Imperfect Contrast in Spanish. Studies in Second Language Acquisition 25: 351-98. [CrossRef]

Montrul, Silvina, and Silvia Perpiñán. 2011. Assessing differences and similarities between instructed heritage language learners and L2 learners in their knowledge of Spanish tense-aspect and mood (TAM) morphology. Heritage Language Journal 8: 90-133. [CrossRef]

Orozco, Rafael. 2005. Distribution of Future time Forms in Northern Colombian Spanish. In Selected Proceedings of the 7th Hispanic Linguistics Symposium. Edited by David Eddington. Somerville: Cascadilla Proceedings Project, pp. 56-65.

Orozco, Rafael. 2007. Colombian Spanish in New York: The Impact of Linguistic Constraints on the Expression of Futurity. In Spanish in Contact: Educational, Social, and Linguistic Inquiries. Edited by Kim Potowski and Richard Cameron. Amsterdam: Benjamins, pp. $311-28$ 
Orozco, Rafael. 2015. Castilian in New York City: What can we Learn from the Future? In New Perspectives on Hispanic Contact Linguistics in the Americas. Edited by Sandro Sessarego and Melvi González Rivera. Frankfurt: Iberoamericana Editorial Vervuert, pp. 347-72.

Orozco, Rafael, and Joshua J. Thoms. 2014. The Future Tense in Spanish L2 Textbooks. Spanish in Context 11: 27-49. [CrossRef]

Pascual y Cabo, Diego. 2015. Issues in Spanish Heritage Morphosyntax. Studies in Hispanic Lusophone Linguistics 8: 389-401. [CrossRef]

Pires, Acrisio, and Jason Rothman. 2009. Disentangling Sources of Incomplete Acquisition: An explanation for Competence Divergence across Heritage Grammars. International Journal of Bilingualism 13: 211-38. [CrossRef]

Polinsky, Maria. 2011. Reanalysis in Adult Heritage Language: A case for attrition. Studies in Second Language Acquisition 33: 305-28. [CrossRef]

Putnam, Michael, and Liliana Sánchez. 2013. What's so Incomplete about Incomplete acquisition? A Prolegomenon to Modeling Heritage Language Grammars. Linguistic Approaches to Bilingualism 3: 478-508. [CrossRef]

R Core Team. 2017. R: A Language and Environment for Statistical Computing; Vienna: R Foundation for Statistical Computing. Available online: http:/ / www.R-project.org/ (accessed on 1 May 2021).

Sedano, Mercedes. 1994. El Futuro Morfológico y la Expresión ir a+ infinitivo en el Español Hablado de Venezuela. Verba 21: 225-40.

Sedano, Mercedes. 2006. Futuro Morfológico y Futuro Perifrástico en la Prensa Escrita. In El Español en América. Diatopia, diacronía e historiografía. Homenaje a José Moreno de Alba en su 65 Aniversario. Edited by Concepción Company. Mexico: Universidad Nacional Autónoma de México, pp. 163-84.

Silva-Corvalán, Carmen. 1994. Language Contact and Change: Spanish in Los Angeles. New York: Oxford University Press.

Silva-Corvalán, Carmen, and Tracy Terrell. 1989. Notas sobre la Expresión de Futuridad en el Español del Caribe. Hispanic Linguistics 2: 191-208.

Stafford, Catherine A., and Clara S. Azevedo. 2015. Variation in Spanish Heritage Speakers' Bilingualism and Cognition. Studies in Hispanic and Lusophone Linguistics 8: 429-39. [CrossRef]

Valdés, Guadalupe. 2000. Introduction. Spanish for Native Speakers: AATSP Professional Development Series Handbook for Teachers K-16. New York: Harcourt College, vol. 3.

Viner, Kevin Martillo. 2018. The Optional Spanish Subjunctive Mood Grammar of New York City Heritage Bilinguals. Lingua 210: 79-94. [CrossRef]

Voeten, Cesko C. 2020. Buildmer: Stepwise Elimination and Term Reordering for Mixed Effects Regression. R Package Version 1.6. Available online: https:/ /CRAN.R-project.org/package=buildmer (accessed on 1 May 2021).

Zentella, Ana Celia. 1997. Growing up Bilingual: Puerto Rican Children in New York. Cambridge: Blackwell Publishers.

Zyzik, Eve. 2019. Incomplete Acquisition from A Usage-Based Perspective: A Response to Domínguez, Hicks, and Slabakova. Studies in Second Language Acquisition 41: 279-82. [CrossRef] 